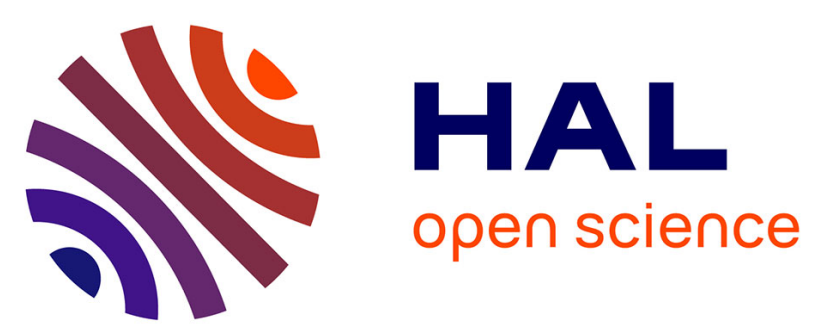

\title{
Estrogen and the selective estrogen receptor modulator (SERM) protection against cell death in estrogen receptor alpha and beta expressing U2OS cells
}

Anu Kallio, Tao Guo, Elisa Lamminen, Jani Seppänen, Lauri Kangas, H.

Kalervo Väänänen, Pirkko Härkönen

\section{To cite this version:}

Anu Kallio, Tao Guo, Elisa Lamminen, Jani Seppänen, Lauri Kangas, et al.. Estrogen and the selective estrogen receptor modulator (SERM) protection against cell death in estrogen receptor alpha and beta expressing U2OS cells. Molecular and Cellular Endocrinology, 2008, 289 (1-2), pp.38. 10.1016/j.mce.2008.03.005 . hal-00532016

\section{HAL Id: hal-00532016 https://hal.science/hal-00532016}

Submitted on 4 Nov 2010

HAL is a multi-disciplinary open access archive for the deposit and dissemination of scientific research documents, whether they are published or not. The documents may come from teaching and research institutions in France or abroad, or from public or private research centers.
L'archive ouverte pluridisciplinaire HAL, est destinée au dépôt et à la diffusion de documents scientifiques de niveau recherche, publiés ou non, émanant des établissements d'enseignement et de recherche français ou étrangers, des laboratoires publics ou privés. 


\section{Accepted Manuscript}

Title: Estrogen and the selective estrogen receptor modulator (SERM) protection against cell death in estrogen receptor alpha and beta expressing U2OS cells

Authors: Anu Kallio, Tao Guo, Elisa Lamminen, Jani Seppänen, Lauri Kangas, H. Kalervo Vääänen, Pirkko

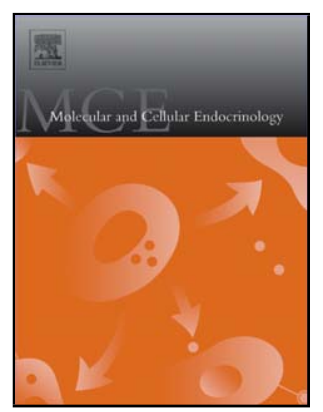
Härkönen

PII: S0303-7207(08)00120-2

DOI: doi:10.1016/j.mce.2008.03.005

Reference: $\quad$ MCE 6845

To appear in: $\quad$ Molecular and Cellular Endocrinology

Received date: $\quad 1-12-2007$

Revised date: $\quad 12-3-2008$

Accepted date: $\quad$ 12-3-2008

Please cite this article as: Kallio, A., Guo, T., Lamminen, E., Seppänen, J., Kangas, L., Väänänen, H.K., Härkönen, P., Estrogen and the selective estrogen receptor modulator (SERM) protection against cell death in estrogen receptor alpha and beta expressing U2OS cells, Molecular and Cellular Endocrinology (2007), doi:10.1016/j.mce.2008.03.005

This is a PDF file of an unedited manuscript that has been accepted for publication. As a service to our customers we are providing this early version of the manuscript. The manuscript will undergo copyediting, typesetting, and review of the resulting proof before it is published in its final form. Please note that during the production process errors may be discovered which could affect the content, and all legal disclaimers that apply to the journal pertain. 
Estrogen and the selective estrogen receptor modulator (SERM) protection against cell death in estrogen receptor alpha and beta expressing U2OS cells

Anu Kallio ${ }^{1,2 *}$, Tao Guo ${ }^{3,4 *}$, Elisa Lamminen ${ }^{1}$ Jani Seppänen $^{1}$, Lauri Kangas ${ }^{5}$, H. Kalervo Väänänen ${ }^{1}$ and Pirkko Härkönen ${ }^{6}$

${ }^{1}$ Institute of Biomedicine, Department of Anatomy, University of Turku, Tykistökatu 6 B, 20520 Turku, Finland

${ }^{2}$ Turku Graduate School of Biomedical Sciences, Turku, Finland

${ }^{3}$ Present address: Institute of Hematology, Union Hospital, Huazhong University of Science and technology, Jiefang Dadao 1277, Wuhan, Hubei 430022, P.R. China.

${ }^{4}$ Present address: Key lab for Bio-targeted Therapy of Hubei Province, Jiefang Dadao 1277, Wuhan, Hubei 430022, P.R. China.

${ }^{5}$ Hormos Medical Ltd, Turku, Finland.

${ }^{6}$ Department of Laboratory Medicine, Lund University, MAS University Hospital, CRC Ent 72, 20502 Malmö, Sweden

Corresponding author:

Pirkko Härkönen

Department of Laboratory Medicine

Lund University, MAS University Hospital

CRC, Ent 72, 20502 Malmö,

Sweden

e-mail: Pirkko.Harkonen@med.lu.se

*The first two authors contributed equally to this work. 


\section{ABSTRACT}

In the current work we compared the ability of $17 \beta$-estradiol $\left(\mathrm{E}_{2}\right)$ and the selective estrogen receptor modulators (SERMs) tamoxifen (Tam), raloxifene (Ral) and ospemifene (Osp) to promote the survival of osteoblast-derived cells against etoposide-induced apoptosis. In order to compare the roles of the two estrogen receptor (ER) isotypes, we created a U2OS human osteosarcoma cell line stably expressing either ERalpha (ER $\alpha)$ or ERbeta (ER $\beta)$. Transfection with either of the ERs was able to render the U2OS cells sensitive to $E_{2}$. We show that $E_{2}$ opposed etoposide-induced apoptosis and that the effect was mediated via both ER isotypes. The ER isotype selective agonists propyl-pyrazole-triol (PPT) and diarylpropionitrile (DPN) had the same effect in U2OS/ER $\alpha$ and U2OS/ER $\beta$ cells, respectively. Osp also opposed apoptosis at least in U2OS/ER $\alpha$ cells. Tam and Ral were not able to protect against etoposide-induced cell death. In order to evaluate the protective effects of $E_{2}$ and Osp upon etoposide challenge we studied the expression of two $E_{2}$-regulated, osteoblast-produced cytokines, IL-6 and OPG in $\mathrm{E}_{2}$ and SERM-treated U2OS/ER $\alpha$ and U2OS/ER $\beta$ cells. Etoposide strongly increased expression of IL-6 and decreased that of OPG. $\mathrm{E}_{2}$ opposed IL-6 increase only in U2OS/ER $\alpha$ cells and OPG decrease primarily in ER $\beta$ cells. Osp opposed the effect of etoposide on OPG primarily in U2OS/ER $\beta$ cells but interestingly, it had little effect on IL-6 expression. E2, PPT, DNP and Osp also inhibited etoposideinduced death and cytokine changes in SAOS-2 osteosarcoma cells expressing endogenous ER $\alpha$ and ER $\beta$. Collectively, our results suggest that the osteoblast protective antiapoptotic effects of $E_{2}$ are mediated by both $E R \alpha$ and $\operatorname{ER} \beta$ but those of Osp primarily by ER $\alpha$. In addition, $\mathrm{E}_{2}$ and Osp opposed the etoposide-induced increase of IL-6 and decrease of OPG which changes would increase osteoclastic activity. These antiresorptive effects of $E_{2}$ and 
Osp upon etoposide challenge differed from each other and they seemed to be differentially mediated in ER $\alpha$ and ER $\beta$ expressing osteoblast-derived U2OS cells.

\section{INTRODUCTION}

Estrogen has recently been demonstrated to protect different types of cells from apoptosis induced by various substances (Bynoe et al., 2000; Haynes et al., 2000; Perillo et al., 2000; Choi et al., 2001; Zhang et al., 2001; Gu et al., 2005; Zheng et al., 2007). The functions of $17 \beta$-estradiol $\left(E_{2}\right)$ are largely mediated through two distinct nuclear estrogen receptor (ER) isoforms, ERalpha $(\mathrm{ER} \alpha)$ and ERbeta $(\mathrm{ER} \beta)$. Moreover, recent work has supported that, in addition to nuclear events, $E_{2}$ is capable of bringing about rapid membrane-initiated signaling events in a variety of cell types (Edwards 2005).

Selective estrogen receptor modulators (SERMs) are compounds that have both estrogen agonistic and estrogen antagonistic properties. They can function in the same way as estrogen in some tissues (e.g. bone) and more like antiestrogen in some other tissues (e.g. breast) and have important clinical applications. For example, tamoxifen (Tam) is widely used in chemotherapy and prevention of breast cancer (Fisher et al., 1998, Radmacher and Simon 2000) and it has also been shown to have a beneficial effect on bone mineral density (BMD) in postmenopausal women (Love et al., 1994, Powles et al., 1996). Raloxifene (Ral) is used in the treatment and prevention of osteoporosis (Jordan 1998; Ettinger et al., 1999; Gradishar et al., 2000; Cicek and Oursler 2006). It also has a strong anticancer effect in breast. Ospemifene (Osp) is a novel SERM that is being developed for the treatment of vaginal 
atrophy in postmenopausal women. It has also shown promise in the prevention and treatment of osteoporosis (Taras et al., 2001, Qu et al., 2000, Komi et al., 2006).

Estrogen has an important role in the development and growth of bones and later in the maintenance of bone mass. It is believed that the major action of estrogen on the skeleton in vivo is through the inhibition of bone resorption (Riggs et al., 2002). Although some of the anti-resorptive effects of estrogen are via direct actions on bone-resorbing osteoclasts, estrogen has also been shown to have indirect effects by regulating bone-forming osteoblasts and bone marrow stromal cells (Zallone 2006). As one of these effects, $\mathrm{E}_{2}$ has been suggested to protect osteoblasts from apoptosis (Kousteni et al., 2001; Chen et al., 2006; Zallone 2006)

Estrogen modulation of osteoclastic bone resorption is mediated, at least in part, by regulating the production of several pro-resorptive factors such as the TNF ligand family member named the receptor activator of nuclear factor $\kappa \mathrm{B}$ ligand (RANKL), interleukin-6 (IL-6) and tumour necrosis factor- $\alpha(\mathrm{TNF}-\alpha)$ by the cells of osteoblastic lineage. Estrogen has also been shown to regulate the synthesis of secreted TNF superfamily member osteoprotegrin (OPG). It acts as a non-signaling decoy receptor for RANKL. OPG regulates bone turnover by preventing RANKL from binding to and activating the signaling receptor RANK on the osteoclast surface. It thus functions as an antiresorptive factor.

The role of osteoblastic/osteocytic apoptosis in the regulation of bone metabolism has been demonstrated by several investigators (Urayama et al., 2000, Kameda et al., 1995, Kawakami et al., 1997, Nakashima et al., 1998, Kawakami et al., 1998, Weinstein et al., 1998). Especially apoptosis of osteoblasts is currently getting more attention since it has been considered to be an important determinant of bone formation and, therefore, of skeletal 
integrity (Manolagas, 2000; Weinstein and Manolagas, 2000). Disorders that promote osteoblastic apoptosis are associated with increased bone fragility (Weinstein et al., 1998), and treatments that inhibit it are associated with anti-fracture efficacy (Jilka et al., 1999).

The aim of the present work was to compare the ability of $E_{2}$ and the osteoprotective SERMs Tam, Ral and Osp to have antiapoptotic effects in osteoblast-derived cells and to evaluate the role of the ER subtypes ERalpha $(E R \alpha)$ and ERbeta $(E R \beta)$ in their cell survival effect. As a model we used the human U2OS osteosarcoma cell line stably expressing either ER $\alpha$ or ER $\beta$. The effects of the SERMs were also studied in another osteoblast-like cell line, SaOS-2 that expresses endogenous $\mathrm{ER} \alpha$ and $\mathrm{ER} \beta$. We demonstrate that $\mathrm{E}_{2}$ and Osp are able to oppose etoposide-induced apoptosis, and that the effect of $E_{2}$ is mediated via both ER isotypes. In addition, the ER isotype selective agonists PPT and DPN selectively opposed apoptosis in $\mathrm{U} 2 \mathrm{OS} / \mathrm{ER} \alpha$ and $\mathrm{U} 2 \mathrm{OS} / \mathrm{ER} \beta$ cells, respectively. We also studied the effect of $\mathrm{E}_{2}$ and Osp on the expression of the osteoblast-produced bone regulatory cytokines IL-6 and OPG in etoposide-treated $\mathrm{U} 2 \mathrm{OS} / \mathrm{ER} \alpha$ and $\mathrm{U} 2 \mathrm{OS} / \mathrm{ER} \beta$ cells. We observed that etoposide treatment caused changes in IL-6 and OPG that would increase osteoclastic activity and bone resorption while the pretreatment of the cells with $E_{2}$ or Osp opposed these changes in a receptor subtype and ligand specific manner.

\section{MATERIALS AND METHODS}

\section{Cell Culture and Preparation of U2OS-ER $\alpha$ and ER $\beta$ Stable Cell Lines}

The U2OS (human osteosarcoma) cells were stably transfected with human ER $\alpha$ or ER $\beta$. 
The following constructs were transfected to U2OS cells together with pcDNA3.1 expression vector which contains a neomycin resistance gene:

1) pSG5-hER $\alpha$ :

Human estrogen receptor $\alpha$ coding sequence: $1,8 \mathrm{~kb}$ in $\mathrm{pSG5}$-vector $(=\mathrm{HEO})$, cloned at the EcoR1 site. In HEO the ER $\alpha$ sequence contains the artificial Gly400Val mutation (GGG to GTG), which destabilizes it in the absence of a ligand. Thus, it gives a lower background and clearer ligand-induced transactivation data than that with wild-type ER $\alpha$ (=HEGO) (Bruder $e t$ al., 1997).

\section{2) $\mathrm{pSG} 5$-hER $\beta$}

Human estrogen receptor $\beta$ coding sequence: $1,6 \mathrm{~kb}$ in pSG5-vector, cloned at the BAMH1 site encoding a full length ER $\beta$ (Fuqua et al., 1999). ER $\beta$ cDNA was PCR-cloned from human ovary mRNA.

Clones were selected with the antibiotic G418 $(0,5 \mathrm{mg} / \mathrm{ml})$. Expression of the ER constructs on U2OS cells was confirmed by RT-PCR, western blotting and immunofluorescence microscopy (data not shown). The trans-activation ability of transfected ER $\alpha$ and ER $\beta$ was detected with an ERE-containing reporter gene. These assays indicated high activity for ER $\alpha$ and moderate activity for $\operatorname{ER} \beta$ (data not shown).

Parental U2OS cells were maintained in McCoy's 5A culture medium supplemented (10\%) with heat-inactivated fetal bovine serum (iFBS), $2 \mathrm{mM}$ L-glutamine, $50 \mathrm{U} / \mathrm{ml}$ penicillin and $50 \mu \mathrm{g} / \mathrm{ml}$ streptomycin. For ER $\alpha$-, ER $\beta$ - and vector transfected U2OS cell medium was supplemented with G-418 $(0,25 \mathrm{mg} / \mathrm{ml})$. SaOS-2 cells were cultured in McCoy's 5A culture 
medium supplemented (15\%) with heat-inactivated fetal bovine serum (iFBS), $2 \mathrm{mM} \mathrm{L-}$ glutamine, $50 \mathrm{U} / \mathrm{ml}$ penicillin and $50 \mu \mathrm{g} / \mathrm{ml}$ streptomycin. For the experiments, cells were grown overnight in phenol-free DMEM/F-12 media containing 0,1\% BSA supplemented with $\mathrm{E}_{2}$, ER ligands or SERMs. According to the cell death analyses, the lowest concentrations to give statistically significant protection against etoposide were $1 \mu \mathrm{M}$ for Osp and $10 \mathrm{nM}$ for $\mathrm{E}_{2}$, PPT and DPN. Thus, we chose to use these drug concentrations also on the following experiments. The pre-incubation time of 24 hrs with SERMs has been previously used also by others (Monroe et al., 2006; Kian Tee et al., 2004, Brady et al., 2002). The incubation times for OPG and IL-6 assays were chosen on the basis of cell death analyses. Treatment times for TNF $\alpha$ and etoposide were one hour and six hours, respectively.

The estrogen-sensitive MCF-7 human breast tumor cell line was originally obtained from the laboratory of Dr. C. K. Osborne (University of Texas Health Science Center, San Antonio, Texas). The cells were maintained in RPMI 1640 culture medium supplemented (10\%) with heat-inactivated fetal bovine serum (iFBS), $2 \mathrm{mM}$ L-glutamine, insulin $(4 \mu \mathrm{g} / \mathrm{ml})$ and $1 \mathrm{nM}$ 17ß-estradiol $\left(\mathrm{E}_{2}\right)$. McCoy's 5A, RPMI, DMEM/F-12, L-glutamine, Tam and insulin were purchased from Sigma (St. Louis, MO) and FBS was purchased from Life Technologies, Inc. (Paisley, Scotland, U.K.). Ral and Osp were from Hormos Medical Oy (Turku, Finland). All drugs were dissolved in DMSO (Sigma, St. Louis, MO).

Confirmation of expression of human ER $\alpha$ in U2OS/ER $\alpha$ cells and human ER $\beta$ in U2OS/ER $\beta$ cells

The expression of transfected ER $\alpha$ and ER $\beta$ in U2OS cells was verified by RT-PCR, Western blotting, immunofluorescence microscopy and reporter gene assays. For RT-PCR analysis the RNAs were isolated from MCF-7, parental U2OS and ER $\alpha$ or ER $\beta$ transfected U2OS cells 
by using the Trizol reagent (Invitrogen) and purified according to the manufacturer's instructions. cDNA was synthetized from $2 \mu \mathrm{g}$ of total RNA in a $20 \mu \mathrm{l}$ reaction containing random hexanucleotides and AMV reverse transcriptase enzyme (Finnzymes, Espoo, Finland). RT-PCR was performed using the Eppendorf Mastercycler. Amplification reactions for ER $\alpha$ were performed for 35 cycles. Successful cDNA synthesis was verified by PCR for GAPDH. The following primers were used:

\begin{tabular}{|c|c|}
\hline $\mathrm{ER} \alpha$ (forward) & 5’- ACA AGC GCC AGA GAG ATG AT -3`' \\
\hline $\mathrm{ER} \alpha$ (reverse) & 5'- AGG ATC TCT AGC CAG GCA CA -3` \\
\hline $\operatorname{ER} \beta$ (forward) & 5`- TGA AAA GGA AGG TTA GTG GGA ACC -3` \\
\hline $\mathrm{ER} \beta$ (reverse) & $5^{\prime}-$ TGG TCA GGG ACA TCA TCA TGG -3` \\
\hline GAPDH (forward) & 5'-AGC CAC ATC GCT CAG ACA C-3’ \\
\hline APDH & 5 '-GCC CAA TAC GAC CAA ATC C-3’ \\
\hline
\end{tabular}

For analysis of expression of ER $\alpha$ and ER $\beta$ by Western blotting, aliquots of whole cell lysate protein $(50 \mu \mathrm{g})$ were separated by SDS-PAGE and transferred to nitrocellulose membranes (Millipore, Billerica, MA). The membranes were blocked with $8 \%$ skimmed milk in TBS/0.05\% Tween-20 and incubated with the primary antibodies for ER $\alpha$ and ER $\beta$ (Santa Cruz Biotechnology). The proteins were visualized using an enhanced chemiluminescence detection system (Amersham Pharmacia Biotech, Uppsala, Sweden) with colored markers (BioRad, Hercules, CA) as size standards.

Immunofluorescence microscopy was used for the localization of transfected ERs in $\mathrm{U} 2 \mathrm{OS} / \mathrm{ER} \alpha$ and U2OS/ER $\beta$ cells. The cells were incubated for 2 hours with ER $\alpha$ or ER $\beta$ specific monoclonal antibodies (Santa Cruz Biotechnology) after which the media were 
replaced with media containing Alexa Fluor 488-conjugated secondary antibody (Molecular Probes) and the cells were further incubated for 45 minutes. The cells were then incubated with DAPI nuclear dye for 10 minutes. Microscopic imaging was carried out on a Zeiss Wide-Field microscope (Zeiss, Jena, Germany).

Luciferase reporter gene assays were used to characterize the functionality of transfected ERs. The U2OS/ER $\alpha$ and U2OS/ER $\beta$ cells were transfected with only a luciferase reporter plasmid under the control of two ER response elements or a human ER $\alpha$ or ER $\beta$ plasmid and the same luciferase reporter plasmid by using Fugene transfection reagent (Roche, Madison, WI). Twenty-four hours after transfection the cells were treated for 24 hours with $10 \mathrm{nM} \mathrm{E} 2$ and the luciferace activity was measured using a dual-luciferase reporter assay according to the manufacturer's instructions (Promega, Madison, WI). For quantitation, in the absence of hormone, the luciferase activity was set to 1 .

\section{IL-6 and OPG $m R N A$ expression}

As previously, total cellular RNA was extracted from the U2OS and SaOS-2 cells using the Trizol reagent and purified according to the manufacturer's instructions. cDNA was synthetized from $2 \mu \mathrm{g}$ of total RNA in a $20 \mu \mathrm{l}$ reaction containing random hexanucleotides and AMV reverse transcriptase enzyme.

\section{Semiquantitative RT-PCR Analysis}

PCR was performed using the Eppendorf Mastercycler. The following primers were used:

TNF $\alpha$ (forward) $\quad 5{ }^{`}$-TGC TTG TTC CTC AGC CTC TT-3`

TNF $\alpha$ (reverse) $\quad 5{ }^{`}$-TGG GCT ACA GGC TTG TCA CT-3`

IL-6 (forward) $\quad 5{ }^{`}$-CCT TCC AAA GAT GGC TGA AA-3` 


\author{
IL-6 (reverse) $\quad 5{ }^{`}$-AGC TCT GGC TTG TTC CTC AC-3` \\ GAPDH (forward) 5`-AGC CAC ATC GCT CAG ACA C-3` \\ GAPDH (reverse) $55^{`}$-GCC CAA TAC GAC CAA ATC C-3`
}

After an initial denaturation at $94^{\circ} \mathrm{C}$ for 3 minutes 25 cycles of PCR amplification were performed, each consisting of a denaturing step of $94{ }^{\circ} \mathrm{C}$ for 30 seconds, annealing at $60{ }^{\circ} \mathrm{C}$ for 30 seconds and extension at $72{ }^{\circ} \mathrm{C}$ for 30 seconds, followed by a final step at $72{ }^{\circ} \mathrm{C}$ for 10 minutes. The number of 25 cycles was selected because in preliminary experiments we verified that with this number of cycles the reaction was still in a linear range for all three genes (data not shown). The amplified fragments were detected by $1,5 \%$ agarose gel electrophoresis and ethidium bromide staining.

\title{
Quantification of apoptotic cells
}

Apoptotic cells were quantified by visualization of changes in nuclear morphology by DAPI staining. Cells $\left(1 \times 10^{5}\right)$ were grown in $3.5-\mathrm{cm}$ diameter Petri dishes with coverslips overnight. Culture media were replaced with DMEM/F12 phenol-red-free media containing $0,1 \%$ BSA and either $E_{2}$, PPT, DPN or SERMs at the concentrations indicated in the results. Non-treated cells served as controls and these cultures had equivalent volumes of DMSO solvent. After 24 hours, etoposide was added to half of the plates for 6 hours. After treatment, the cells were fixed with 3\% paraformaldehyde and the coverslips were mounted on the slides with Vectashield mounting medium with DAPI (Vector Laboratories Inc. Burlingame, CA). Microscopic imaging was carried out on a Zeiss Wide-Field microscope (Zeiss, Jena, Germany). Fifteen areas of $1300 \times 1000$ pixels in one sample were randomly selected from the image for quantification of apoptotic cells. Data of three independent experiments are presented as the percentage of dead cells (means \pm SE) for each treatment. 


\section{Quantitative real-time PCR}

Real-time quantitative PCR analysis was carried out using a 5700 Sequence Detector (PE Applied Biosystems, Foster City, CA, USA). Amplification reactions were set up in $25 \mu 1$ reaction volumes containing amplification primers and SYBR Green PCR Master Mix (PE Applied Biosystems, Foster City, CA). The primer concentrations and cDNA sample volumes were optimized for each primer set. Primer sequences for IL-6, OPG and $\beta$-actin were as follows:

IL-6 (forward) 5’TACCCCCAGGAGAAGATTCC-3`

IL-6 (reverse) 5`-AAAGAGGCACTGGCAGAAAA-3`

OPG (forward) 5 '-TGCAGTACGTCAAGCAGGAG -3`

OPG (reverse) 5`-TGTATTTCGCTCTGGGGTTC -3`

$\beta$-actin (forward) 5 '-CGTGGGCCGCCCTAGGCACCA -3`

$\beta$-actin (reverse) 5`- TTGGCCTTAGGGTTCAGGGGG-3`

Amplifications were performed in 96-well reaction plates. Calibration curves were derived for each gene following serial dilutions of a stock cDNA which were then used as standards. Calibration curves were run in parallel in triplicates for each analysis. Each sample was analyzed three times during each experiment. The experiments were carried out three times on each cell line. Amplification data were analysed using the Sequence Detector System Software (PE Applied Biosystems). The results were normalized to $\beta$-actin and expressed as a percentage of controls.

OPG assay

Cell culture media were collected, and OPG was determined with ELISA according to the manufacturer's instructions (Biomedica, Wien, Austria). Briefly, standards, samples, positive 
control, assay buffer, and detection antibody were pipetted into a 96-well plate precoated with monoclonal anti-OPG antibody and mixed. After incubation for $24 \mathrm{~h}$ at $+4^{\circ} \mathrm{C}$, the plate was washed five times with washing buffer, streptavidin peroxidase conjugate was added to the wells, and the cells were incubated for $1 \mathrm{~h}$ at room temperature. The plate was washed five times, and tetramethylbenzidine was added as a substrate to develop the color reaction. After incubation for 20 minutes at room temperature, stop solution was added, and OPG was measured with a Victor model 2 instrument (EG \& G Wallac) at 450-nm absorbance.

\section{IL-6 assay}

Similarly to the OPG assay, cell culture media were collected, and IL-6 was determined with ELISA according to the manufacturer's instructions (Sanquin, Amsterdam, The Netherlands). Briefly, standards, samples, positive control, assay buffer, and detection antibody were pipetted into a 96-well plate precoated with monoclonal anti-IL-6 antibody and mixed. After incubation for $24 \mathrm{~h}$ at room temperature, the plate was washed five times with washing buffer; standards and samples were added to the wells and incubated for $1 \mathrm{~h}$ at room temperature. Wells were washed again as previously after which biotinylated antibody was added and the plate was incubated for 1 hour at room temperature. After a third wash streptavidin-HRP conjugate was added to the wells, and the plate was incubated for $30 \mathrm{~min}$ at room temperature. The plate was washed, and tetramethylbenzidine was added as a substrate to develop the color reaction. After incubation for 30 minutes I the dark at room temperature, stop solution was added, and IL-6 was measured with a Victor model 2 instrument (EG \& G Wallac) at 450-nm absorbance. 


\section{Statistical analyses}

The statistical significance of differences between the vehicle control and the etoposidetreated sample $(+)$, vehicle control and $E_{2}$, Osp, PPT and DPN treated samples (\#) or etoposide-treated cells and cells treated with a combination of etoposide and ER ligands (*) were determined by one-way analysis of variance (ANOVA). The critical value for significance was $P<0,05$ (a, b). Values are given as means \pm SE.

\section{RESULTS}

Expression of estrogen receptors $\alpha$ and $\beta$ in U2OS human osteosarcoma cells

U2OS human osteosarcoma cells do not endogenously express ERs at a detectable level. However, the U2OS cells stably transfected with expression constructs for the human ER $\alpha$ and ER $\beta$ full length sequences expressed the receptors at RNA and protein level as demonstrated by RT-PCR and Western blotting (Fig.1A and B). Translocation of ER $\alpha$ and ER $\beta$ to the nuclei was observed in $E_{2}$-treated transfectants but not in U2OS parent cells in immunofluorescence microscopy (Fig. 1C). The transactivation capacity of transfected ERs was confirmed by ERE-luciferase reporter gene assays (Fig. 1D). In the presence of 10nM E 2 , there was a seventy-fold increase in luciferase activity in ER $\alpha$ transfected cells, which indicates a high level of receptor activity (Fig. 1D). Transient expression of ER $\alpha$ in U2OS/ER $\alpha$ cells further increased luciferase expression. In the case of U2OS/ER $\beta, E_{2}-$ treatment resulted in a five-fold increase in luciferase activity thus indicating a moderate level of receptor activity (Fig. 1D). Luciferase expression was not increased by transient transfection of ER $\beta$ to $\mathrm{U} 2 \mathrm{OS} / \mathrm{ER} \beta$ cells. 


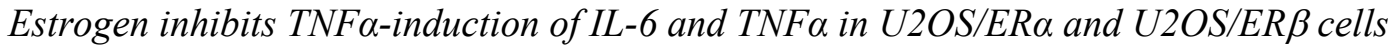

In order to further confirm that transfected ERs are functional in U2OS cells, we studied whether ER $\alpha$ and $E R \beta$ are able to restore the effects of $E_{2}$ on TNF $\alpha$-induced production of IL-6 and TNF $\alpha$ itself in U2OS/ER $\alpha$ cells and U2OS/ER $\beta$ cells, respectively. The ability of estrogen to decrease the expression of these cytokines in osteoblastic cells has previously been shown by several researchers (Spelsberg et al., 1999; Brady et al., 2002 Khosla et al., 2002). Transfected U2OS cells were incubated overnight with $0,1 \mathrm{nM}$ or $1 \mathrm{nM} \mathrm{E}$, after which cells were either treated for one hour with $5 \mathrm{ng} / \mathrm{ml} \mathrm{TNF} \alpha$ or left untreated. Control cells received vehicle $(0.2 \%$ DMSO) only. Total RNAs were then isolated and $\mathrm{TNF} \alpha$-induced production of IL-6 and TNF $\alpha$ was studied by semi-quantitative RT-PCR. In ER $\alpha$-transfected U2OS cells $E_{2}$ at a concentration of $0,1 \mathrm{nMol} / \mathrm{L}$ was able to oppose $\mathrm{TNF} \alpha$-induced production of the TNF $\alpha$ and IL-6 (Fig. 2). In the case of U2OS/ER $\beta$, a higher concentration of $1 \mathrm{nM} \mathrm{E}_{2}$ was required to inhibit production of either of the two cytokines studied. However, both U2OS/ER $\alpha$ cells and U2OS/ER $\beta$ cells were found to respond to estrogen treatment. In parental U2OS cells $\mathrm{E}_{2}$ had no effect on production of either TNF $\alpha$ or IL-6.

E2 and ER isotype selective agonists PPT and DPN oppose apoptosis in U2OS/ERa and U2OS/ER $\beta$ cells

Next we studied the ability of $E_{2}$ to protect against etoposide-induced cell death in parental and ER-transfected cells. A 6-h treatment of U2OS parental cells with etoposide markedly increased the relative number of dead cells (data not shown). Pretreatment of the parental U2OS cells with $\mathrm{E}_{2}$ for $24 \mathrm{~h}$ did not affect the etoposide effect. Similar results were obtained in $\mathrm{U} 2 \mathrm{OS} /$ mock cells pretreated with $\mathrm{E}_{2}$ or with the ER $\alpha$ and ER $\beta$ agonists PPT and DPN (Fig. 3A). However, in $\mathrm{U} 2 \mathrm{OS} / \mathrm{ER} \alpha$ and $\mathrm{U} 2 \mathrm{OS} / \mathrm{ER} \beta$ cells $\mathrm{E}_{2}$ was able to protect against etoposide-induced cell death (Fig. 3B and C). Addition of $\mathrm{E}_{2}$ together with etoposide resulted 
in almost $40 \%$ and $50 \%$ decrease in the number of dead cells, respectively, when compared to treatment with etoposide only. Similarly, the U2OS/ER $\alpha$ specific agonist PPT was also able to decrease the number of dead cells close to the level observed in $E_{2}$-treated U2OS/ER $\alpha$ cells, whereas the decreasing effect of DPN in U2OS/ER $\beta$ cells was not statistically significant. $\mathrm{E}_{2}$, PPT and DPN alone did not increase the rate of cell death compared with the vehicle treatment.

\section{Ospemifene prevents etoposide-induced cell death in U2OS/ERa cells}

In order to study whether the bone sparing selective estrogen receptor modulators (SERMs) Tam, Ral and Osp have estrogen-like antiapoptotic or proapoptotic effect in the ER $\alpha$ - and ER $\beta$ - transfected U2OS cells, we pre-incubated the cells with $1 \mu \mathrm{M}$ of these SERMs for 24 hours before 6 hours of $100 \mu \mathrm{M}$ etoposide treatment. We observed that only $\mathrm{E}_{2}$ and Osp were able to oppose etoposide -induced apoptotic cell death in U2OS/ER $\alpha$ cells in a statistically significant way (Fig. 4A). Treatment of ER $\alpha$-transfected cells with both etoposide and $E_{2}$ resulted in $38 \%$ less cell death than treatment with etoposide only. In the case of Osp instead of $\mathrm{E}_{2}$, this level was $41 \%$.

In U2OS/ER $\beta$ cells Osp was not able to oppose etoposide -induced cell death as well as in U2OS/ER $\alpha$ cells, since treatment with both Osp and etoposide together resulted in only approximately $15 \%$ decrease in the number of dead cells when compared with treatment with etoposide only (Fig. 4B). Tam and Ral were not able to significantly prevent apoptosis in the U2OS/ER $\alpha$ and U2OS/ER $\beta$-transfected cells. None of the SERMs studied was able to oppose etoposide -induced death of mock -transfected U2OS cells (data not shown). 
$E_{2}$ and Osp oppose etoposide-induced decrease of OPG expression

In order to study how the antiapoptotic $\mathrm{E}_{2}$ and Osp influenced the characteristic function of osteoblastic cells exposed to apoptosis inducing factor we examined the expression of OPG and IL-6 in etoposide-treated ER $\alpha$ and ER $\beta$ containing U2OS cells. U2OS ER $\alpha$, U2OS ER $\beta$ and control cells were first incubated overnight with either $1 \mu \mathrm{M}$ Osp or $10 \mathrm{nM}$ concentration of $E_{2}$, PPT or DPN after which $100 \mu \mathrm{M}$ etoposide was added to cultures for six hours, after which OPG expression was detected with real-time quantitative PCR. We found that, while etoposide-treatment significantly decreased OPG production in both ER $\alpha$ and ER $\beta$ transfected cells, all ligands showed a tendency to oppose the effects of etoposide on OPG expression (Fig. 5A and 5B). In ER $\beta$-transfected cells $\mathrm{E}_{2}$ did not induce expression of OPG as efficiently as Osp and DPN, since the mRNA expression level in the samples treated with a combination of $\mathrm{E}_{2}$, Osp or DPN and etoposide was $20 \%, 55 \%$ and $65 \%$, higher, respectively, when compared with the sample treated with etoposide only. In the case of vector-transfected U2OS/mock cells, $\mathrm{E}_{2}$, Osp did not oppose etoposide-induced decrease of OPG expression (data not shown).

Next we used a sensitive sandwich ELISA method to measure OPG protein concentrations in the conditioned media collected after treating the cells as above for QRT-PCR. As seen in Fig.6A, in ER $\alpha$-transfected U2OS cells treated with a combination of etoposide and PPT, the OPG concentration was approximately $5 \mathrm{pM}$, whereas in the sample treated with etoposide alone the OPG concentration was $3 \mathrm{pM}$. The effect of PPT was also statistically significant. In the case of ER $\beta$-transfected U2OS cells (Fig. 6B) the OPG concentrations in the samples treated with combinations of etoposide and either $\mathrm{E}_{2}$, Osp or DPN were $13 \mathrm{pM}, 9 \mathrm{pM}$ and 12 pM, respectively, while in the sample treated with etoposide solely, the OPG concentration 
was approximately 2,5 pM. This indicated that all the ligands tested were able to prevent the effects of etoposide on the production of OPG.

The effects of $E_{2,} P P T, D P N$ and Osp on IL-6 expression in ER-transfected U2OS cells

We also studied the effect of $\mathrm{E}_{2}$, PPT, DNP and Osp on the expression and production of IL-6 in etoposide-treated U2OS cells containing ER $\alpha$ and ER $\beta$. IL-6 has been demonstrated to increase osteoclastic activity (Manolagas 1995, Manolagas et al., 2002) and $\mathrm{E}_{2}$ has previously been shown to downregulate cytokine-induced expression of IL-6 in osteoblasts (Manolagas et al., 2002). U2OS/ER $\alpha, \mathrm{U} 2 \mathrm{OS} / \mathrm{ER} \beta$ and mock-transfected cells were first incubated for 24 hours with either $10 \mathrm{nM} \mathrm{E}$, $10 \mathrm{nM}$ PPT, $10 \mathrm{nM}$ DPN or $1 \mu \mathrm{M}$ Osp after which $100 \mu \mathrm{M}$ etoposide was added to cultures for six hours after which IL-6 expression was determined with real-time quantitative PCR. Control cells were treated with vehicle (0.2\% DMSO) only. Fig 7A shows that in U2OS /ER $\alpha$ cells etoposide strongly induced IL-6 expression (approximately two-fold) when compared to vehicle-treated cells and after addition of $\mathrm{E}_{2}$ or PPT the level of IL-6 expression was even lower than in control cells. However, Osp could not oppose the effect of etoposide on IL-6 expression. In U2OS ER $\beta$-cells (Fig. 7B), addition of $\mathrm{E}_{2}$, Osp or DPN together with etoposide opposed etoposide-induced increase in IL-6 expression to some extent, but this effect was not statistically significant.

To study the effects of ER ligands on IL-6 production, we used ELISA to measure protein concentrations in the media collected from the cells treated as for RNA measurements. In ER $\alpha$-transfected U2OS cells etoposide significantly increased the level of IL-6 protein secretion when compared to the vehicle (DMSO) -treated sample. All ER-ligands tested opposed the effect of etoposide since after addition of $E_{2}$, Osp or PPT the IL-6 protein levels were approximately $57 \%, 30 \%$ and $45 \%$ lower when compared to the sample treated with 
etoposide only. The effects of $\mathrm{E}_{2}$ and PPT were statistically significant. However, in the case of U2OS/ER $\beta$ cells, none of the ER ligands tested opposed etoposide-induced IL-6 secretion at a statistically significant level (Fig.8B).

The effects of $E_{2}, P P T, D P N$ and Osp on SaOS-2 cells

In addition to U2OS cells, we also studied the effects of different ER ligands on another osteoblast-like cell line, SaOS-2, which, unlike the parent U2OS cells, expresses both ER $\alpha$ and ER $\beta$. We found that all ER ligands tested ( $E_{2}$, Osp, PPT and DPN) significantly decreased etoposide-induced apoptosis (Fig. 9A). In addition, all ER ligands used opposed etoposide-induced decrease of OPG expression to some extent, but only the effect of DPN was statistically significant (Fig. 9B). Furthermore, we observed that $\mathrm{E}_{2}$, Osp, PPT and DPN also opposed the effect of etoposide on IL-6 mRNA expression (Fig. 9C).

\section{DISCUSSION}

Recent data from our laboratory indicates that $\mathrm{E}_{2}$ is able to protect breast cancer cells against tamoxifen-induced cell death (Zheng et al., 2007). Other reports have shown evidence for estrogen inhibition of apoptosis induced by various substances in other cell types (Bynoe et al., 2000; Haynes et al., 2000; Perillo et al., 2000; Choi et al., 2001; Zhang et al., 2001). In addition to osteoclast-directed actions, inhibition of osteoblast and osteocyte apoptosis has been proposed as one potential mechanism in estrogen maintenance of bone mass (Kousteni et al., 2001; Gu et al., 2005; Chen et al., 2006; Zallone 2006; Jilka et al., 2007). $\mathrm{E}_{2}$ has been shown to protect calvaria-derived osteoblastic cells from etoposide-induced apoptosis (Kousteni et al., 2001; Zallone 2006) as well as to protect osteoblasts from ethanol-induced 
bone loss (Chen et al., 2006). We have recently demonstrated that $\mathrm{E}_{2}$ opposes glucocorticoidinduced apoptosis of primary osteocytes (Gu et al., 2005).

In this work we compared the ability of Tam, Ral and Osp, which are known to have bonesparing effects, with $\mathrm{E}_{2}$ and synthetic ER isoform specific ligands PPT and DNP to promote the survival of osteoblast-derived osteosarcoma cells. In addition, we asked which of the two ER isotypes plays the predominant role in mediating the effects of $E_{2}$ and SERMs. To examine the individual actions of $\operatorname{ER} \alpha$ and $\operatorname{ER} \beta$ we used the U2OS human osteosarcoma cell line that lacks detectable endogenous ER expression to produce cell lines that stably express ER $\alpha$ and ER $\beta$. The transfected ERs seemed to be functional in terms of nuclear translocation and activated transcription of a reporter gene upon $\mathrm{E}_{2}$ stimulation. The obtained cell lines also responded appropriately to TNF $\alpha$ stimulation by decreased TNF $\alpha$ and IL-6 expression. Corresponding cell lines have also been created and used by others for various purposes (Monroe et al., 2003; Stossi, et al., 2004 and Kian Tee et al., 2004). To examine whether the results obtained with U2OS cells also apply to other osteoblastic cells, we studied the effects of $E_{2}$ and other ER ligands on apoptosis of another osteoblast-derived osteosarcoma cell line SaOS-2, which is known to express both ER $\alpha$ and ER $\beta$ (Sutherland et al., 1996, Vidal et al., 1999). In addition to ER expression, there are differences between the U2OS and SaOS-2 cell lines that potentially influence the antiapoptotic actions of ER ligands in these cells. For example, U2OS cells are known to be p53 positive, whereas SaOS-2 cells lack p53, which may affect their apoptotic responses (Sandoval et al., 2004; Olijslagers et al., 2007). Our results demonstrate, however, that ER ligands were able to protect both of these cell lines against drug-induced apoptosis. 
Apoptosis of osteoblasts can be induced by various substances including for example cancer chemotherapy drugs and oxidative stress. We used etoposide at an osteoblast apoptosis inducing concentration (Urayama et al., 2000). Etoposide is a chemotherapy drug that is given as a treatment for some types of cancer (osteosarcoma included) and it has previously been used to study apoptosis of osteoblastic cells (Li et al., 2001; Kousteni et al., 2003; Plotkin et al., 2006). Etoposide binds to the enzyme topoisomerase II and inhibits its function of ligating cleaved DNA molecules, which ultimately leads to apoptotic cell death. Our hypothesis was that, despite the nature of the apoptotic stimulus, $\mathrm{E}_{2}$ and some other ER ligands such as SERMs can induce activation of an independent survival-signaling pathway in the cells. Indeed, existence of such ER-mediated antiapoptotic pathways has been described in osteoblasts (Kousteni et al., 2001; Kousteni et al., 2003).

Our findings suggest that both estrogen receptor isotypes are able to mediate the pro-survival effects of $E_{2}$. The protective effect of $E_{2}$ was not observed in ER-negative parental (data not shown) or vector-transfected U2OS cells, which supports the conclusion that the antiapoptotic effect is mediated mainly via estrogen receptors. In addition, in SaOS-2 cells both PPT and DPN were able to oppose etoposide-induced effects, indicating the involvement of both $E R \alpha$ and $E R \beta$. ER $\alpha$ has been demonstrated to play the primary role in the protective effects of $\mathrm{E}_{2}$ on bone structure (McDougall et al., 2003; McCauley et al., 2003; Vidal et al., 2000). However, earlier in vivo and in vitro results from our laboratory (Parikka et al. 2005; Michael et al., 2007) as well as studies by others (Sims et al 2003) also suggest a role for ER $\beta$ in maintaining bone mass at least in females. We hypothesize that the mechanisms observed in the present study may contribute to these effects.

The bone sparing SERMs Tam, Ral and Osp differed in their ability of protecting the osteoblastic cells from threatening death. The SERM Osp showed anti-apoptotic capacity but 
Tam and Ral did not have corresponding effect. Ral has been reported to decrease sodium nitroprusside-induced apoptosis of osteoblasts (Olivier et al., 2005) but in our experimental setup Ral did not protect the osteoblastic cells against etoposide-induced apoptosis. Corresponding finding has previously been done by Kousteni et al. (Kousteni et al., 2003). Furthermore, van Essen et al. (van Essen et al., 2007) did not find any evidence for of Ral effect on osteocyte apoptosis, either. These results suggest that the anti-osteoporotic actions of Ral are obtained by other means than opposing osteoblast apoptosis. Such effects could be Ral inhibition of osteoclast formation (Taranta et al., 2002, Ramalho et al., 2002; Manolagas et al. 2000) and downregulation of the production of bone resorption enhancing cytokines by osteoblastic cells (Taranta et al., 2002, Cheung et al., 2003). In addition, Ral enhances OPG production and suppresses IL-6 secretion in normal human osteoblastic cells that express predominantly ER $\alpha$ (Viereck et al., 2003).

In contrast to Ral, Osp was found to partly share the anti-apoptotic capacity of $E_{2}$. The ability of Osp to protect osteoblastic cells from apoptosis has not been demonstrated previously. Unlike $E_{2}$, Osp seemed to signal anti-apoptotic effects mainly via ER $\alpha$. Like Ral, also Osp has been shown to decrease bone resorption (Komi et al., 2004). However, Osp seems to enhance osteoblastic differentiation with a mechanism that differs from that of Ral (Qu et al. 1999). Komi et al. (2006) have recently reported that Osp and Ral differentially affect markers for osteoblastic and osteoclastic activities in postmenopausal women.

To further compare the response of ER $\alpha$ and ER $\beta$-transfected cells to $E_{2}$ and other ER ligands, we studied the ability of these compounds to modulate etoposide-induced effects on the expression of IL-6 and OPG, which are two important bone regulatory cytokines. OPG acts as a decoy receptor of osteoblast and stromal cell -produced RANKL and contributes to 
decreased osteoclastic activity and bone resorption (Syed and Khosla 2005). $E_{2}$ has previously been demonstrated to increase osteoblastic OPG mRNA and protein levels in a dose dependent way (Saika et al., 2001, Lindberg et al., 2001, Bord et al., 2003; Hofbauer et al., 1999). Our results demonstrate that in U2OS/ER $\beta$ cells Osp and DPN opposed the effects of etoposide on the expression of OPG, while in ER $\alpha$-transfected cells the etoposide opposing effect of the ligands was less pronounced. This suggests that the regulation of OPG is primarily mediated by ER $\beta$. The role of ER $\beta$ in OPG regulation was further supported by the finding that in SaOS-2 cells DPN presented the most marked etoposide-opposing effect. Not just OPG, but also RANKL and the ratio of RANKL/OPG are important in the modulation of bone homeostasis by estrogen (Bord et al., 2003; Bashir et al., 2005). However, our U2OS cell lines appeared to produce RANKL at a very low level and we were unable to assess the RANKL/OPG ratio in a reliable way. Low RANKL expression by osteoblastic cell lines has also been previously reported by others (Hofbauer et al., 1999, Cheung et al., 2003).

IL-6 is a regulator of immune and inflammatory responses that strongly stimulates osteoclasts and bone resorption (Compston 2001; Manolagas et al., 2002). It may also affect osteoblastic cells. The stimulatory effect of etoposide on IL-6 production has previously been demonstrated (Verdenqh et al., 2002, Wood et al., 2006, Tozava et al., 2002), although there are also conflicting reports (Verdrenqh et al., 2003, De Vita et al., 1998). Estrogens have previously been shown to regulate the induction of IL-6 by various cytokines that modulate osteoclastic bone resorption (Messalli et al., 2007, Compston et al., 2001). We found that etoposide strongly induced expression of IL-6 in osteoblastic cells and in the case of ER $\alpha$ both $\mathrm{E}_{2}$ and PPT opposed this effect. In U2OS ER $\beta$ cells, none of the ER ligands inhibited the etoposide-increased IL-6 expression in a statistically significant way. These results 
suggest that $E_{2}$ regulates IL-6 expression primarily via $E R \alpha$. Interestingly, in contrast to $E_{2}$, Osp did not significantly affect IL-6 expression in U2OS cells containing ER. It did, however, oppose the effect of etoposide on IL-6 expression in SaOS-2 cells, suggesting ER $\beta$ contribution and a cell-specific effect. Differences in the levels of ER expression in SaOS-2 cells and ER-transfected U2OS cells and in the ratio of ER $\alpha$ and ER $\beta$ as well as the relative binding affinities of $E_{2}$ and Osp to these receptors may explain various IL-6 responses of the two cell lines. Altogether, the results suggest that the bone-protective mechanisms of Osp (Qu et al., 2000) differ from those of $\mathrm{E}_{2}$.

Different SERM responses of U2OS-based and Saos-2 cells also reflect the heterogeneity of the osteosarcoma cells lines. As transformed cells they can only partially represent osteoblasts, which fact limits the interpretation of the results considering normal bone function. The aim of this study was, however, to evaluate of the SERM actions and the roles of ER isoforms in osteoblast-derived cellular models that are available. Even with the abovementioned limitations the results suggest that the anti-apoptotic and anti-resorptive responses of osteoblast-derived cells to SERMs are highly ligand and ER subtype-specific.

Cumulatively, the ability of $E_{2}$ and certain SERMs to oppose IL-6 increase and OPG decrease upon exposure to compounds that promote osteoblastic cell apoptosis primarily seem to contribute to the inhibition of bone resorption. Exploiting these mechanisms may help to maintain bone homeostasis and prevent osteoblastic death in association with various drug treatments. Understanding these mechanisms would also be needed when planning hormonal treatment for osteoporosis or chemotherapies for bone tumours or metastatic bone diseases that interfere with IL-6 and/or OPG-related systems. 


\section{ACKNOWLEDGEMENTS}

This research was supported by the Sigrid Jusélius Foundation, the Academy of Finland, the Cancer Association of South-western Finland, the Foundation of Jalmari and Rauha Ahokas, the Turku University Foundation, the Orion-Farmos Research Foundation, the Finnish Breast Cancer Group, the Zonta District 20 and the Lilly Foundation. We would like to acknowledge Dr Mike Nelson (University of Turku, Finland) for the revision of the language and MSc Irina Lisinen (University of Turku, Finland) for performing the statistical analyses.

\section{REFERENCES}

Bashir A, Mak YT, Sankaralingam S et al. Changes in RANKL/OPG/RANK gene expression in peripheral mononuclear cells following treatment with estrogen or raloxifene. Steroids 2005; 70: 847-855

Bord S, Ireland DC, Beavan SR and Compston JE. The effects of estrogen on osteoprotegerin, RANKL, and estrogen receptor expression in human osteoblasts. Bone 2003; 32: $136-141$

Brady H, Doubleday M, Gayo-Fung L, Hickman M, Khammungkhune S, Kois A, Lipps S, Pierece S, Richard N, Shevlin G, Sutherland MK, Anderson D, Bhagwat S and Stein B. Differential response of estrogen receptors $\alpha$ and $\beta$ to SP500263, a novel potent selective estrogen receptor modulator. Mol Pharm 2002; 61: 562-568 
Bruder JM, Sobek L, Oettel M et al. Dehydroepiandrosterone stimulates the ERE. J Steroid Biochem Mol Biol 1997; 62: 461-466

Bynoe M, Grimaldi C and Diamond B. Estrogen up-regulates Bcl-2 and blocks tolerance induction of naive B cells. Proc Natl Acad Sci 2000; 97: 2703-2708

Chen J-R, Haley RL, Hidestrand M, Shankar K, Liu X, Lumpkin CK, Simpson P, Badger T and Ronis M. Estradiol protects against ethanol-induced bone loss by inhibiting up-regulation of receptor activator of nuclear factor- $\mathrm{\kappa B}$ ligand in osteoblasts. J Pharm Exp Ther 2006; 319: $1182-1190$

Cheung J, Mak YT, Papaioannou S, Evans BAJ, Fogelman I and Hampson G. Interleukin-6 (IL-6), IL-1, receptor activator of nuclear factor kappaB ligand (RANKL) and osteoprotegerin production by human osteoblastic cells: comparison of the effects of 17-beta oestradiol and raloxifene. $J$ Endo 2003; 177: 423-433

Chipoy C, Brounais B, Trichet V, Bataglia S, Berrur M, Oliver L, Juin P, Redini F, Heymann $\mathrm{O}$ and Blanchard F. Sensitization of osteosarcoma cells to apoptosis by oncostatin M depends on STAT5 and p53. Oncogene 2007; 26: 6653-6664

Choi K, Kang S, Tai C, Auersperg N and Leung P. Estradiol up-regulates antiapoptotic Bcl-2 messenger ribonucleic acid and protein in tumorigenic ovarian surface epithelium cells. Endochrinology 2001; 142: 2351-2360 
Cicek M and Oursler MJ. Breast cancer bone metastasis and current small therapeutics. Cancer Meatastasis Rev 2006; 25: 635-644

Compston JE. Sex steroids and bone. Physiol Rev 2001; 81: 419-447

De Vita F, Orditura M, Auriemma A, Infusino S, Roscigno A and Catalano G. Serum levels of interleukin-6 as a prognostic factor in advanced non-small cell lung cancer. Oncol Rep 1998; 5: 649-692

Duan Z, Lamendola DE, Penson RT, Kronish KM and Seiden MV. Overexpression of IL-6 but not IL-8 increases paclitaxel resistance of U2OS human osteosarcoma cells. Cytokine 2002; 7: 234-2427

Eriksen EF, Colvard DS, Berg NJ, Graham ML, Mann KG, Splelberg TC and Riggs BL. Evidence of estrogen receptors in normal human osteoblast-like cells. Science; 1998; 241: 8486

Ettinger B, Black DM, Mitlak BH, et al. Reduction of vertebral fracture risk in postmenopausal women with osteoporosis treated with raloxifene: results from a 3-year randomized clinical trial. Multiple outcomes of Raloxifene Evaluation (MORE) Investigators. JAMA 1999; 282: 637-45

Fisher B, Constantino JP, Wickerham CD, et al. Tamoxifen for prevention of breast cancer: Report of the National Surgical Adjuvant Breast and Bowel project P-1 study. J Natl Cancer Inst 1998; 90: 1371-1388 
Fuqua SA, Schiff R and Parra I et al. Expression of wild-type ER $\beta$ and variant isoforms in human breast cancer. Cancer Res 1999; 59: 5425-5428

Gradishar W, Glusman J, Lu Y, Vogel C, Cohen FJ and Sledge GW Jr. Effects of high dose raloxifene in selected patients with advanced breast carcinoma. Cancer 2000; 88: 2047-2053 Gu G, Hentunen TA, Nars M, Härkönen PL and Väänänen HK. Estrogen protects primary osteocytes against glucocorticoid-induced apoptosis. Apoptosis 2005; 10:583-595

Haynes M, Sinha D, Russell K, Collinge M, Fulton D, Morales-Ruiz M, Sessa WC and Bender JR. Membrane estrogen receptor engagement activates endothelial nitric oxide synthase via the PI3K-kinase-Akt pathway in human endothelial cells. Circ Res 2000; 87: $677-682$

Hofbauer LC, Khosla S and Dunstan CR. Estrogen stimulates gene expression and protein production of osteoprotegerin in human osteoblastic cells. Endocrinology 1999; 140: 43674370

Jilka RL, Weinstein RS, Bellido T, Parfitt AM and Manolagas SC. Osteoblast programmed cell death (apoptosis): modulation by growth factors and cytokines. J Bone Miner Res 1998;13:793-802

Jilka RL, Weinstein RS, Parfitt AM and Manolagas SC. Quantifying osteoblast and osteocyte apoptosis: challenges and rewards. J Bone Miner Res 2007; 22: 1492-1501

Jordan VC. Designer estrogens. Scientific American 1998; 279: 60-67 
Kameda $\mathrm{T}$, Ishikawa $\mathrm{H}$ and Tsutsumi $\mathrm{T}$. Detedtion and characterization of apoptosis in osteoclasts in vitro. Biochem Biophys Res Commun 1995; 207: 753-760

Kawakami A, Eguchi K, Matsuoka N, Tsuboi M, koji T and Urayama S. Fas and Fas ligand interaction is necessary for human osteoblast apoptosis. J Bone Miner Res 1997; 12: 16371646

Khosla S, Atkinson EJ, Dunstan CR and O'Fallon WM. Effect of estrogen versus testosterone on circulating OPG and other cytokine levels in normal elderly men. $J$ Clin Endocrinol Metab 2002; 87: 1550-1554

Kian Tee M, Rogatsky I, Tzagarakis-Foster C, Cvoro A, An J, Christy R, Ymamamoto K and Leitman D. Estradiol and selective estrogen receptor modulators differentially regulate target genes with estrogen receptors $\alpha$ and $\beta$. Mol Biol Cell 2004; 15: 1262-1272

Komi J, Heikkinen J, Rutanen EM, Halonen K, Lammintausta R and Ylikorkala O. Effects of ospemifene, a novel SERM, on biochemical markers of bone turnover in healthy postmenopausal women. Gynecol Endocrinol. 2004; 18:152-158

Komi J, Lankinen K, DeGregorio M, Heikkinen J, Saarikoski S, Tuppurainen M, Halonen K, Lammintausta R, Väänänen $\mathrm{K}$, Ylikorkala $\mathrm{O}$ and Erkkola R. Effects of ospemifene and raloxifene on biochemical markers of bone turnover in postmenopausal women. $J$ Bone Miner Metab 2006; 24: 314-318 
Kousteni S, Bellido T, Plotkin LI, O’Brien CA, Bodenner DL, Han L, Han K, DiGregorio GB, Katzenellenbogen BS, Katzenellenbogen PK, Roberson PK, Weinstein RS, Jilka RL and Manolagas SC. Nongenotropic, sex-nonspesific signalling through the estrogen or androgen receptors: dissociation from transcriptional activity. Cell 2001; 104: 719-730

Kousteni S, Chen J-R, Bellido T, Han L, et al. Reversal of bone loss in mice by nongenotropic signaling of sex steroids. Science 2002; 298: 843

Kousteni S, Han L, Chen J-R, Almeida M, Plotkin L, Bellido T and Manolagas S. Kinasemediated regulation of common transcription factors accounts for the bone-protective effects of sex steroids. J Clin Invest 2003; 111: 1651-1664

Li F, Zhang D and Fujise K. Characterization of fortilin, a novel antiapoptotic protein. J Biol Chem 2001; 276: 47542-47549

Lindberg MK, Erlandsson M, Alatalo SL, Windahl S, Andersson G, Halleen JM, Carlsten H, Gustafsson JA and Ohlsson C. Estrogen receptor alpha, but not estrogen receptor beta, is involved in the regulation of the OPG/RANKL (osteoprotegerin/receptor activator of NFkappa B ligand) ratio and serum interleukin-6 in male mice. J Endocrinol 2001; 171: 425-433

Lipton A, Theriault RL, Hortobagyi GN, Simeone J, Knight RD, Mellars K, Reitsma DJ, Heffernan M and Seaman J. Pamidronate prevents skeletal complications and is effective palliative treatment in women with breast carcinoma and osteolytic bone metastases: long term follow-up of two randomized, placebo-controlled trials. Cancer 2000; 88: 1082-1090 
Love RR, Barden HS, Mazess RB, Epstein S and Chappell RJ. Effect of Tamoxifen on lumbar spine bone mineral density in postmenopausal women after 5 years. 1994 Arch Intern Med 28: 2585-2588

Manolagas SC, Kousteni S and Jilka RL. Sex steroids and bone. Recent Prog Horm Res $2002 ; 57: 385-409$

Manolagas SC. Birth and death of bone cells: basic regulatory mechanisms and implications for the pathogenesis and treatment of osteoporosis. Endocr Rev 2000; 21:115-137

Manolagas SC. Role of cytokines in bone resorption. Bone 1995; 17: 63S-67S

Mastro A, Gay C, Welch D, Donahue H, Jewell J, Mercer R, DiGirolamo D, Chislock E and Guttridge K. Breast cancer cells induce osteoblast apoptosis: a possible contributor to bone degradation. J Cell Biochem 2004; 91: 265-276

Mendez-Davila C, Garcia-Moreno C, Turbi C and de la Piedra C. Effects of 17beta-estradiol, tamoxifen and raloxifene on the protein and mRNA expression of interleukin-6, transforming growth factor-beta1 and insulin-like growth factor-1 in primary human osteoblast cultures.

McCauley LK, Tözum TF, Kozloff M, Koh-Paige AJ, Chen C, Demeshkjen M, Cronovich H, Richard V, Keller ET, Rosol TJ and Goldstein SA. Transgenic models of metabolic bone disease: impact of estrogen receptor deficiency on skeletal metabolism. Connect Tissue Res2003; 44: 250-263

Mercer R, Miyasaka C and Mastro A. Metastatic breast cancer cells suppress osteoblasts adhesion and differentiation. Clin Exp Metastasis 2004; 21: 427-435 
Messalli E, Mainini G, Scaffa C, Cafiero A, Salzillo PL, Ragucci A and Cobellis L. Raloxifene therapy interacts with serum osteoprotegerin in postmenopausal women. Maturitas 2007; 56: 38-44

Michael H, Härkönen PL, Kangas L, Väänänen HK and Hentunen TA. Differential effects of selective oestrogen receptor modulators (SERMs) on human osteoclasts in vitro. Br J Pharm. 2007: 1-12

Monroe D, Getz B, Johnsen S, Riggs B, Khosla S and Spelsberg T. Estrogen receptor isoform-spesific regulation of endogenous gene expression in human osteoblastic cell lines expressing either ER $\alpha$ or ER $\beta$. J Cell Biochem 2003; 90: 315-326

Monroe D, Secreto F, Hawse J, Subramaniam M, Khosla L and Spelsberg TC. Estrogen receptor isoform-spesific regulation of the retinoblastoma-binding protein 1 (RBBP1) gene: roles of AF1 and enhancer elements. J Biol Chem 2006; 281: 28596-28604

Nakashima T, Sasaki H, Tuboi M, Kawakami A, Fyjiyama K and Kiriyama T. Inhibitory effect of glugocorticoid for osteoblast apoptosis induced by activated peripheral blood mononuclear cells. Endocrinology 1998; 139: 2032-2040

Olijslagers S, Zhang Y-H, Backendorf C and Noteborn M. Additive cytotoxic effect of Apoptin and chemotherapeutic agents paclitaxel and etoposide on human tumour cells. Basic Clin Pharmacol Toxicol 2007; 100: 127-131 
Olivier S, Fillet M, Malaise M, Piette J, Bours V, Merville MP and Franchimont M. Sodium nitroprusside-induced osteoblast apoptosis is mediated by long chain ceramide and is decreased by raloxifene. Biochem Pharmacol 2005; 69: 891-901

Parikka V, Peng Z, Hentunen T, Risteli J, Elo T, Väänänen HK and Härkönen P. Estrogen responsiveness of bone formation in vitro and altered bone phenotype in aged estrogen receptor-alpha-deficient male and female mice. Eur J Endocrinol 2005; 152: 301-314

Perillo B, Sasso A, Abbondanza C and Palumbo G. 17beta-estradiol inhibits apoptosis in MCF-7 cells, inducing bcl-2 expression via two estrogen-responsive elements present in the coding sequence. Mol Cell Biol 2000; 20: 2890-2901

Plotkin L, Manolagas S and Bellido T. Dissociation of the pro-apoptotic effects of bisphosphonates on osteoclasts from their anti-apoptotic effects on osteoblasts/osteocytes with novel analogs. Bone 2006; 39: 443-452

Powles TJ, Hickish T, Kanis JA, Tidy A and Ashley S. Effect of Tamoxifen on bone mineral density measured by dual-energy x-ray absorptiometry in healthy premenopausal and postmenopausal women. J Clin Oncol 1996; 14: 78-84

Qu Q, Härkönen PL and Väänänen HK. Comparative effects of estrogen and antiestrogens on differentiation of osteoblasts in bone marrow culture. J Cell Biochem 1999; 73: 500-507

Qu Q, Zheng H, Dahllund J, et al. Selective estrogenic effects of a novel triphenylethylene compound, FC1271a, on bone, cholesterol level and reproductive tissues in intact and ovariectomized rats. Endocrinology 2000; 141: 809-820 
Radmacher MD and Simon R. Estimation of tamoxifens's efficiency for preventing the formation and growth of breast tumors. J Natl Cancer Inst 2000; 92: 48-53

Ramalho AC, Couttet P, Baudoin C, Morieux C, Graulet AM; de Vernejoul MC and CohenSolal ME. Estradiol and raloxifene decrease the formation of multinucleate cells in human bone marrow cultures. Eur Cytokine Netw. 2002; 13: 99-145

Riggs BL, Khosla S and Melton 3rd LJ. A unitary model for involutional osteoporosis: estrogen deficiency causes both type I and type II osteoporosis in postmenopausal women and contributes to bone loss in aging men. J Bone Miner Res 1998; 13:763-773

Riggs BL, Khosla S and Melton LJ.Sex steroids and the construction and concervation of adult skeleton. Endocr Rev 2002; 23: 279-302

Saika M, Inoue D, Kido S and Matsumoto T. 17ß-estrdiol stimulates expression of osteoprotegerin by a mouse stromal cell line, ST-2, via estrogen receptor- $\alpha$. Endocrinology 2001; 142: 2205-2212

Sandoval R, Xue J, Pilkinton M, Salvi D, Kiyokawa H and Colamoncini O. Induction of apoptosis requires ARF but not p53 in osteosarcoma cell lines. J Biol Chem 2004; 279: $32275-32280$

Sims N, Clement-Lacroix P, Minet D, Fraslon- Vanhulle C, gaillard-Kelly M, Resche-Rigon $\mathrm{M}$ and Baron R. A functional androgen receptor is not sufficient to allow estradiol to protect bone after gonadectomy in estradiol receptor-deficient mice. J Clin Invest 2003; 111: 13191327 
Spelsberg TC, Subramamiam M, Riggs BL and Khosla 1999. The actions and interactions of sex steroids and growth factors/cytokines on the skeleton. Mol Endo 1999; 13: 819-828

Stossi F, Barnett D, Frasor J, Komm B, Lyttle R and Katzenellenbogen B. Transcriptional profiling of estrogen-regulated gene expression via estrogen receptor (ER) $\alpha$ or ERß in human osteosarcoma cells: Distinct and common target genes for these receptors. Endocrinology 2004; 145: 3473-3486

Sutherland MK, Hui DU, Rao LG, Wylie JN and Murray TM. Immunohistochemical localization of the estrogen receptor in human osteoblastic SaOS-2 cells, association of receptor levels with alkaline phosphatase activity. Bone 1996; 18: 361-369

Syed F and Khosla S. Mechanisms of sex steroid effects on bone. Biochem Biophys Res Commun 2005; 328: 688-696

Taranta A, Brama M, teti A, De Luca V, Scandurra R, Spera G, Agnusdei D, termine J and Migliaccio S. The selective estrogen receptor modulatorm Raloxifene regulates osteoclast and osteoblasts activity in vitro. Bone 2002; 30: 368-376

Taras TL, Wurz GT and DeGregorio MW. In vitro and in vivo biologic effects of ospemifene (FC-1271a) in breast cancer. J Steroid Biochem Mol Biol 2001; 77: 271-279

Tozava K, Okamoto T, Hayashi Y, Sasaki S, Kawai N and Kohri K. N-acetyl_L-cysteine enhances chemotherapeutic effect on prostate cancer cells. Urol Res 2002; 30: 53-58 
Urayama S, Kawakami A, Nakashima T, Tsuboi M, Yamasaki S, Hida A, Ichinose Y, Nakamura H, Ejima E, Aoyagi t, Nakamura T, Migita K, Kawabe y and Eguchi K. Effect of vitamin K2 on osteoblast apoptosis: vitamin K2 inhibits apoptotic cell death of human osteoblasts induced by Fas, proteasome inhibitor, etoposide, and staurosporine. J Lab Clin Med 2000; 136: 181-193

Van Essen HW, Holzmann PJ, Blankenstein MA, Lips P and Bravenboer N. Effect of raloxifene treatment on osteocyte apoptosis in postmenopausal women. Calcif Tissue Int 2007; 81: 183-190

Verdengh M, Johnsson IM, Zaether O, Bajtner E, Holmadahl R and Tarkowski A. Total abrogation of collagen II-induced arthritis and the B cell response to type II collagen using suboptimal doses of a topoisomerase II antagonist. Ann Rheum Dis 2002; 61: 829-831

Verdenqh $\mathrm{M}$ and Tarkowski A. Impact of topoisomerase II inhibition on cytokine and chemokine production. Inflamm Res 2003; 52: 148-153

Vidal O, Kindblom LG and Ohlsson C. Expression and localization of estrogen receptor-beta in murine and human bone. J Bone Miner Res 1999; 14: 923-929

Viereck V, Grundker C, Blascheke S, Niederkleine B, Siggelkow H, froch K-H, Raddatz D, Emons G and Hofbauer L. Raloxifene concurrently stimulates osteoprotegerin and inhibits interleukin-6 production by human trabecular osteoblasts. J Clin Endocr Metab 2003; 88:4206-4213 
Weinstein RS SC and Manolagas. Apoptosis and osteoporosis Am J Med 2000; 108: 153-164 Weinstein RS, Jilka RL, Parfitt AM and Manolagas SC. Inhibition of osteoblastogenesis and promotion of apoptosis of osteoblasts and osteocytes by glucocorticoids. Potential mechanisms of their deleterious effects on bone. J Clin Invest 1998; 102: 274-282

Wood LJ, Nail LM, Perrin NA, Elsea CR, Fisher A and Drucker BJ. The cancer chemotherapy drug etoposide (VP-16) induces proinflammatory cytokine production and sickness behavior-like symptoms in a mouse model of cancer chemotherapy-related symptoms. Biol Res Nurs 2006; 8: 157-169

Zallone A. Direct and indirect estrogen actions on osteoblasts and osteoclasts. Ann N Y Acad Sci 2006; 1068: 173-9

Zhang Y, Touneksti O, Akerman B, Goodyer C and LeBlanc A. 17-beta-estradiol induces an inhibitor of active caspases. J Neurosci 2001; 21: RC176

Zheng A, Kallio A and Härkönen P. Tamoxifen-induced Rapid Death of MCF-7 Breast Cancer Cells is mediated via ERK Signaling and can be abrogated by Estrogen. Endocrinology 2007; 148: 2764-2777.

\section{FIGURE LEGENDS}

Fig.1. Confirmation of expression of human ER $\alpha$ in U2OS/ER $\alpha$ cells and human ER $\beta$ in U2OS/ER $\beta$ cells. 
U2OS cells were stably transfected with either ER $\alpha$ or ER $\beta$ and expression of ERs was detected by RT-PCR (A). Human ER $\alpha$ and ER $\beta$ cDNA plasmids were used as a positive control and GADPH served as a loading control. Western blotting was used to detect the expression of ER $\alpha$ and ER $\beta$ proteins (B). Antibody specificity was verified with recombinant human ER $\alpha$ or ER $\beta$ and MCF-7 whole cell lysates. Localization of transfected ER $\alpha$ and ER $\beta$ was detected by immunofluorescence microscopy (C). Reporter gene assays were used to measure the $E_{2}$-induced activity of transfected ERs (D). U2OS/ER $\alpha$ or U2OS/ER $\beta$ cells were transfected with only a luciferase reporter plasmid under the control of two ER response elements, or a human ER $\alpha$ or ER $\beta$ plasmid and the same luciferase reporter plasmid. In the absence of hormone, the luciferase activity was set to 1 .

Fig.2. Estrogen inhibits TNFa-induction of IL-6 and TNFa in U2OS/ER a and U2OS/ER $\beta$ cells

Parental U2OS cells and U2OS cells transfected with either ER $\alpha$ or ER $\beta$ were incubated overnight with $0,1 \mathrm{nM}$ or $1 \mathrm{nM} \mathrm{E}$, after which cells were either treated for one hour with $5 \mathrm{ng} / \mathrm{ml} \mathrm{TNF} \alpha$ or left untreated. Control cells received vehicle (0.2\% DMSO) only. Total RNAs were then isolated and TNF $\alpha$-induced production of IL-6 and TNF $\alpha$ was studied by semi-quantitative RT-PCR. The experiment was carried out three times, with comparable results.

Fig.3. ER isotype selective agonists PPT and DPN oppose apoptosis in U2OS/ERa and U2OS/ER $\beta$ cells

U2OS cells transfected with either vector (A), ER $\alpha(B)$, or ER $\beta$ (C) were first incubated overnight with either $10 \mathrm{nM}$ PPT, $10 \mathrm{nM}$ DPN or $10 \mathrm{nM} \mathrm{E}$ after which $100 \mu \mathrm{M}$ etoposide was added to cultures for six hours to induce apoptosis. Control cells were treated with 
vehicle $(0.2 \%$ DMSO) only. Dead cells were visualized by means of nuclear staining under fluorescence microscope. Fifteen areas of $1300 \times 1000$ pixels in one sample were randomly selected from each plate for quantification of apoptotic cells. Data of three independent experiments are presented as the percentage of dead cells (means \pm SE) for each treatment. The statistical significance of differences between vehicle control and etoposide-treated sample $(+)$ or etoposide-treated cells and cells treated with combination of etoposide and ER ligands $(*)$ were determined one-way analysis of variance (ANOVA).

\section{Fig.4. Ospemifene prevents apoptosis of $\mathrm{U} 2 \mathrm{OS} / \mathrm{ER} \alpha$ cells}

ER $\alpha$ - (A) or ER $\beta$ (B) -transfected cells were pre-incubated with either $10 \mathrm{nM} \mathrm{E}, 0,01 \mu \mathrm{M}$ or $1 \mu \mathrm{M}$ Tam, $0,01 \mu \mathrm{M}$ or $1 \mu \mathrm{M}$ Ral or $0,01 \mu \mathrm{M}$ or $1 \mu \mathrm{M}$ Osp for overnight before 6 hours of etoposide treatment, after which cell death was determined by microscopic visualization of apoptotic nuclei. Control cells were treated with vehicle (0.2\% DMSO) only. Results are presented as the percentage of dead cells (means \pm SE). The statistical significance of differences between vehicle control and etoposide-treated sample $(+)$ or etoposide-treated cells and cells treated with combination of etoposide and ER ligands $(*)$ were determined one-way analysis of variance (ANOVA).

\section{Fig.5. The effects of $E_{2}$, PPT and Osp on etoposide-induced decrease of OPG expression}

$\mathrm{ER} \alpha-(\mathrm{A})$ or $\mathrm{ER} \beta$ (B) -transfected cells were pre-incubated with or without either $10 \mathrm{nM} \mathrm{E}_{2}, 1$ $\mu \mathrm{M}$ Osp or $10 \mathrm{nM}$ PPT/DPN for overnight before 6 hours of etoposide treatment, after which OPG expression was detected by quantitative PCR. Control cells were treated with vehicle $(0.2 \%$ DMSO) only. The columns represent values of three independent experiments (mean $\pm \mathrm{SE}$ ). The statistical significance of differences between either vehicle control and etoposide- 
treated sample $(+)$ or etoposide-treated cells and cells treated with combination of etoposide and ER ligands (*) were determined one-way analysis of variance (ANOVA).

Fig.6. The effects of $E_{2}$, PPT and Osp on etoposide-induced decrease of OPG protein secretion

ER $\alpha$ - (A) or ER $\beta$ (B) -transfected U2OS cells were pre-incubated with either $10 \mathrm{nM} \mathrm{E}, 1 \mu \mathrm{M}$ Osp or $10 \mathrm{nM}$ PPT/DPN for overnight before 6 hours of etoposide treatment, after which OPG expression was determined by ELISA. Control cells were treated with vehicle $(0.2 \%$ DMSO) only. The columns represent values of three independent experiments (mean $\pm \mathrm{SE}$ ). The statistical significance of differences between either vehicle control and etoposide-treated sample (+) or etoposide-treated cells and cells treated with combination of etoposide and ER ligands $(*)$ were determined one-way analysis of variance (ANOVA).

Fig.7. The effects of $E_{2}$, PPT and Osp on etoposide-induced increase of IL-6 expression $\mathrm{ER} \alpha-(\mathrm{A})$ or $\mathrm{ER} \beta$ (B) -transfected cells were pre-incubated with or without either $10 \mathrm{nM} \mathrm{E}_{2}, 1$ $\mu \mathrm{M}$ Osp or $10 \mathrm{nM}$ PPT/DPN for overnight before 6 hours of etoposide treatment, after which IL-6 expression was detected by quantitative PCR. Control cells were treated with vehicle $(0.2 \%$ DMSO) only. The columns represent values of three independent experiments (mean $\pm \mathrm{SE})$. The statistical significance of differences between either vehicle control and etoposidetreated sample $(+)$ or etoposide-treated cells and cells treated with combination of etoposide and ER ligands $(*)$ were determined one-way analysis of variance (ANOVA).

Fig.8. The effects of $E_{2}$, PPT and Osp on etoposide-induced decrease of IL-6 protein secretion. 
ER $\alpha$ - (A) or ER $\beta$ (B) -transfected U2OS cells were pre-incubated with either $10 \mathrm{nM} \mathrm{E} 2,1 \mu \mathrm{M}$ Osp or $10 \mathrm{nM}$ PPT/DPN for overnight before 6 hours of etoposide treatment, after which IL-6 expression was determined by ELISA. Control cells were treated with vehicle (0.2\% DMSO) only. The columns represent values of three independent experiments (mean $\pm \mathrm{SE}$ ). The statistical significance of differences between vehicle control and etoposide-treated sample $(+)$ or etoposide-treated cells and cells treated with combination of etoposide and ER ligands (*) were determined one-way analysis of variance (ANOVA).

\section{Fig.9. The effects of $\mathrm{E}_{2}$, Osp, PPT and DPN on SaOS-2 cells}

SaOS-2 cells were incubated with either $10 \mathrm{nM} \mathrm{E}_{2}, 1 \mu \mathrm{M}$ Osp, $10 \mathrm{nM}$ PPT or $10 \mathrm{nM}$ DPN for overnight and then treated with etoposide for six hours after which cell death was determined by microscopic visualization of apoptotic nuclei (A). Alternatively, cells were treated similarly, after which expression of OPG (B) or IL-6 (C) was detected by quantitative PCR. The statistical significance of differences between either vehicle control and etoposide-treated sample $(+)$,vehicle control and $E_{2}$, Osp, PPT and DPN treated samples (\#) or etoposidetreated cells and cells treated with combination of etoposide and ER ligands (*) were determined one-way analysis of variance (ANOVA).

Table 1. Summary of the effects of $\mathrm{E}_{2}, \mathrm{PPT}, \mathrm{DNP}$ and Osp on the etoposide-induced cell death and changes in expression of OPG and IL-6 in U2OS/ER $\alpha, \mathrm{U} 2 \mathrm{OS} / \mathrm{ER} \beta$ and SaOS-2 cells. 
A)

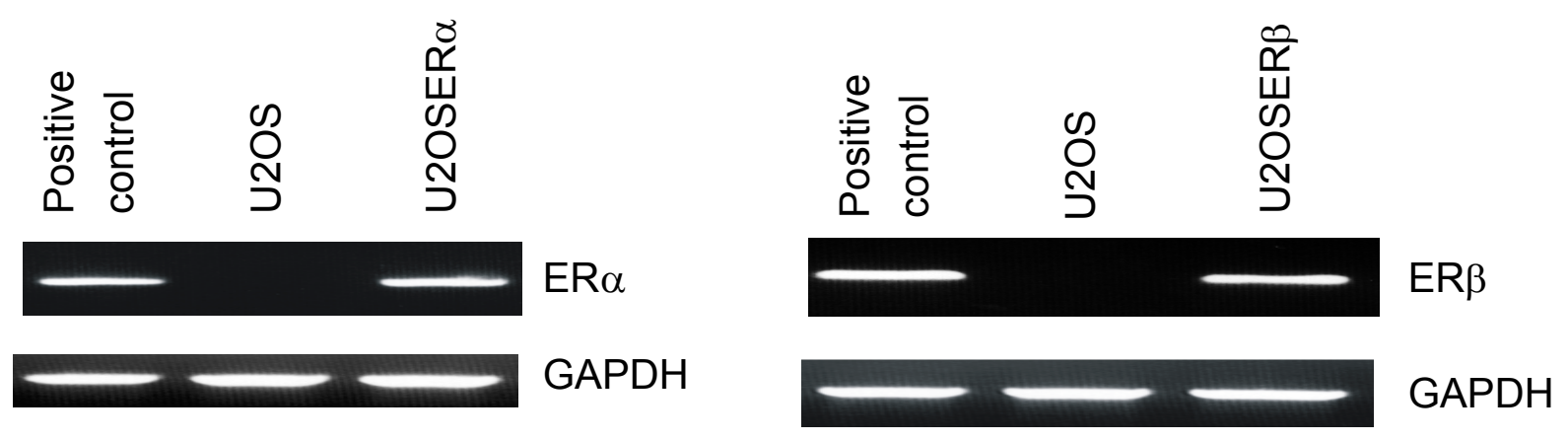

B)

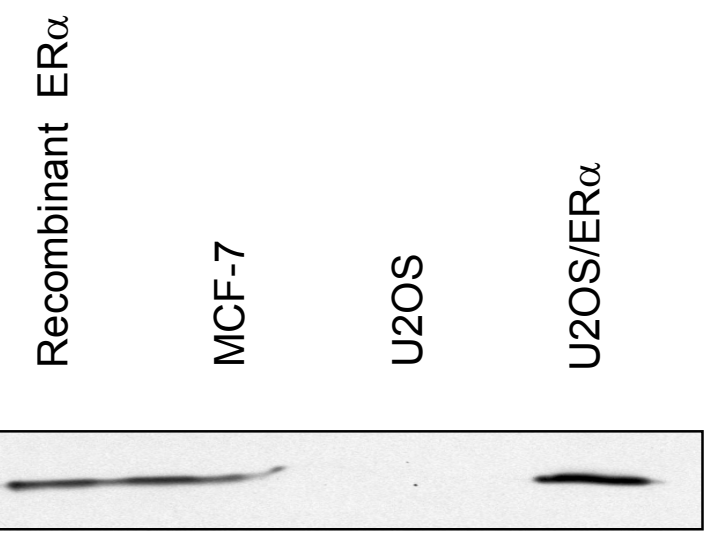

$\frac{n}{}$

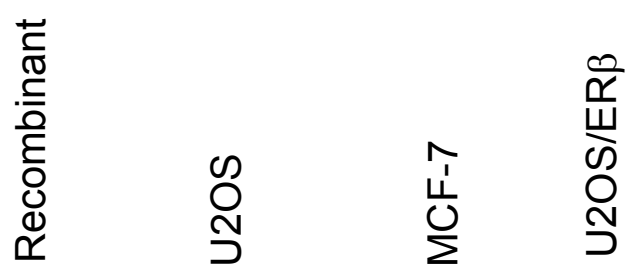

Figure 1. 
C)

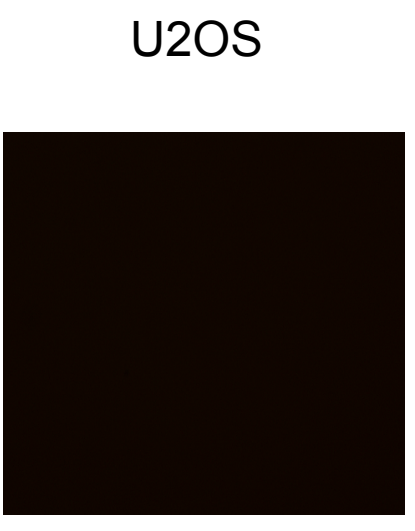

U2OS/ER $\alpha$

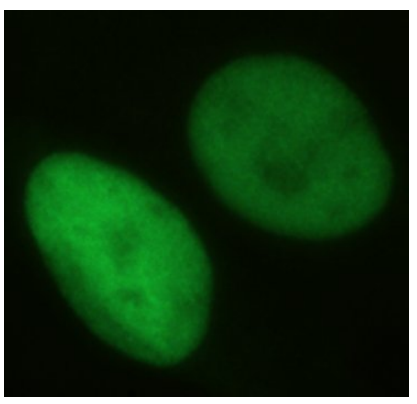

D)

U2OS/ER $\alpha$

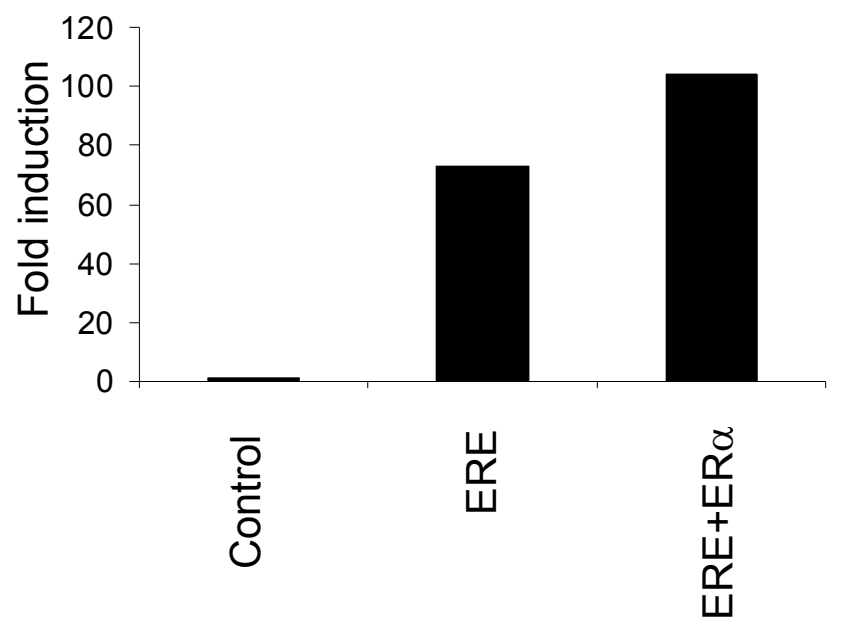

U2OS/ER $\beta$

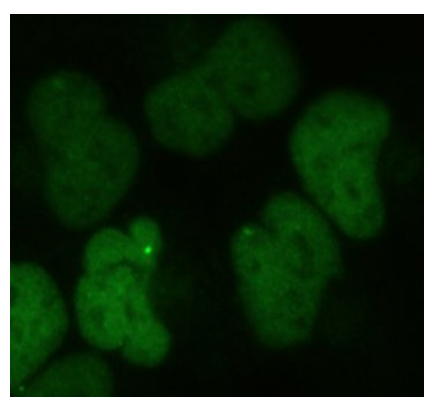

U2OS/ER $\beta$

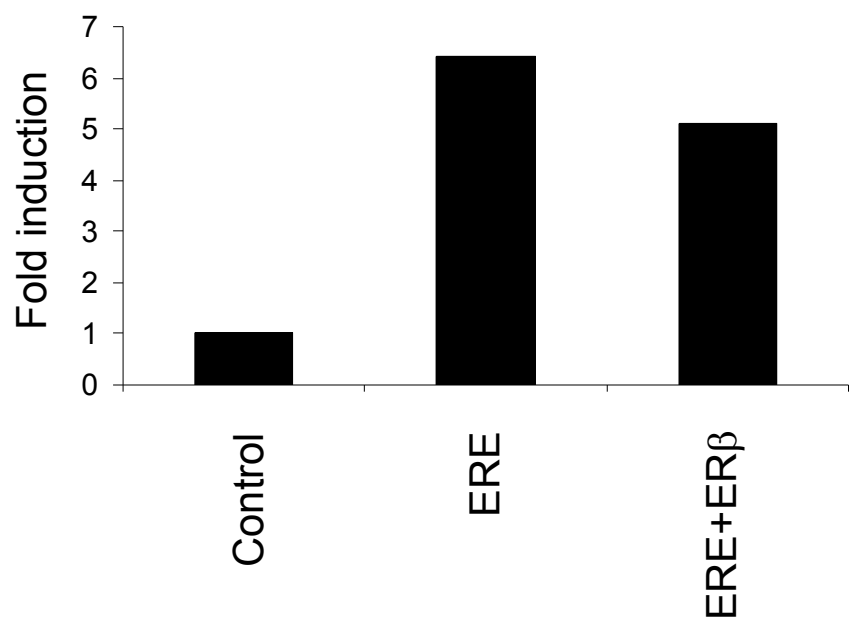

Figure 1. 


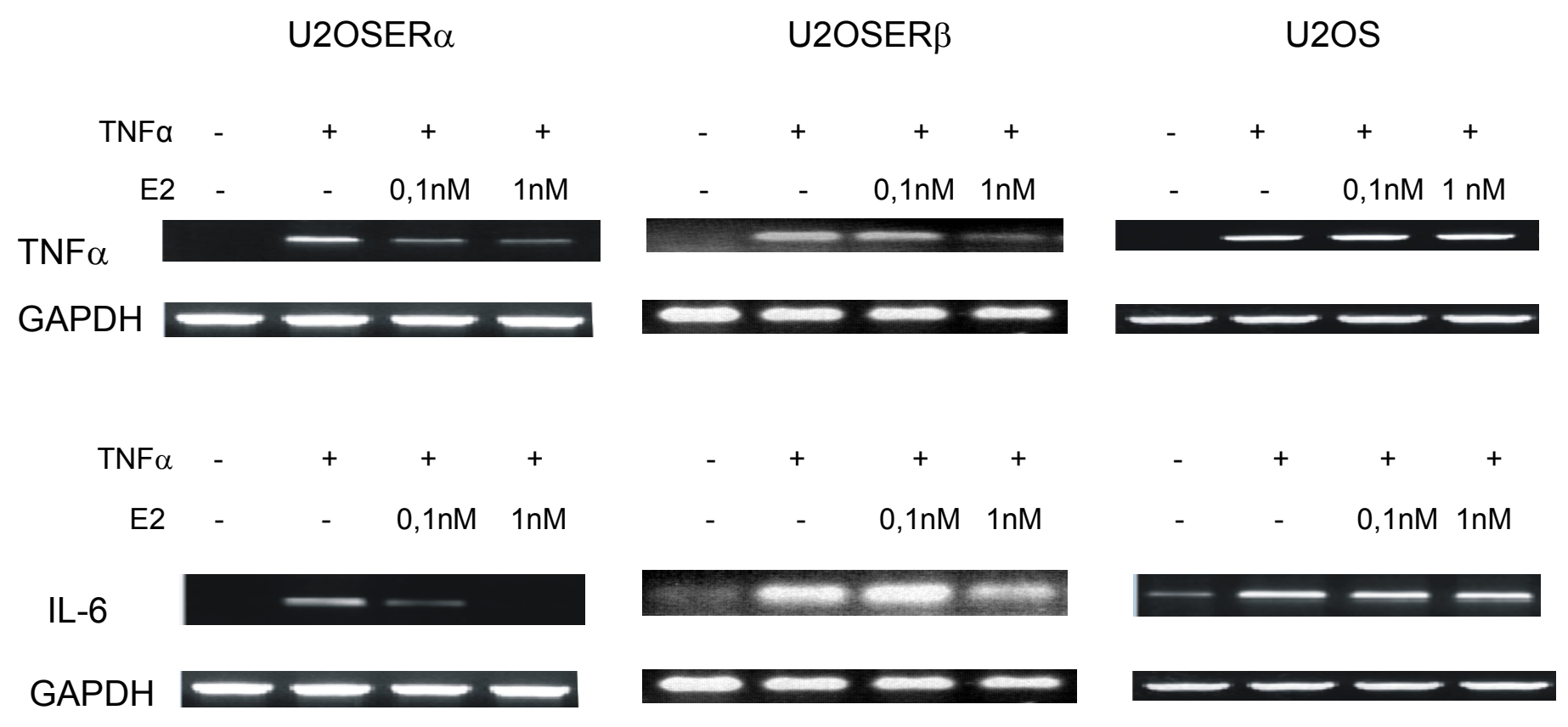

Figure 2. 
A)

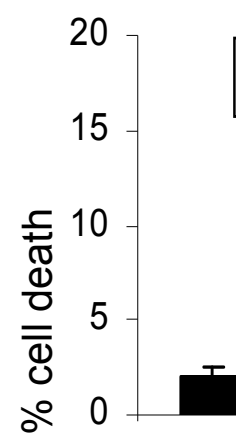

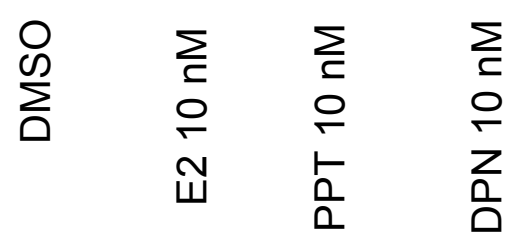

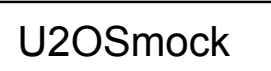

B)

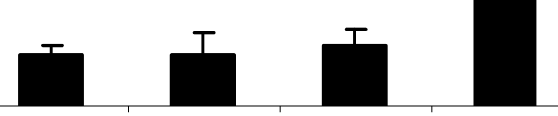

$\sum_{I} \sum_{I} \sum_{I} \sum_{I} \sum_{i}$

응 응응ㅇㅇ응

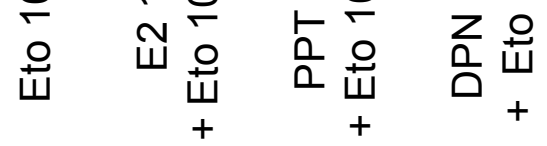

C)
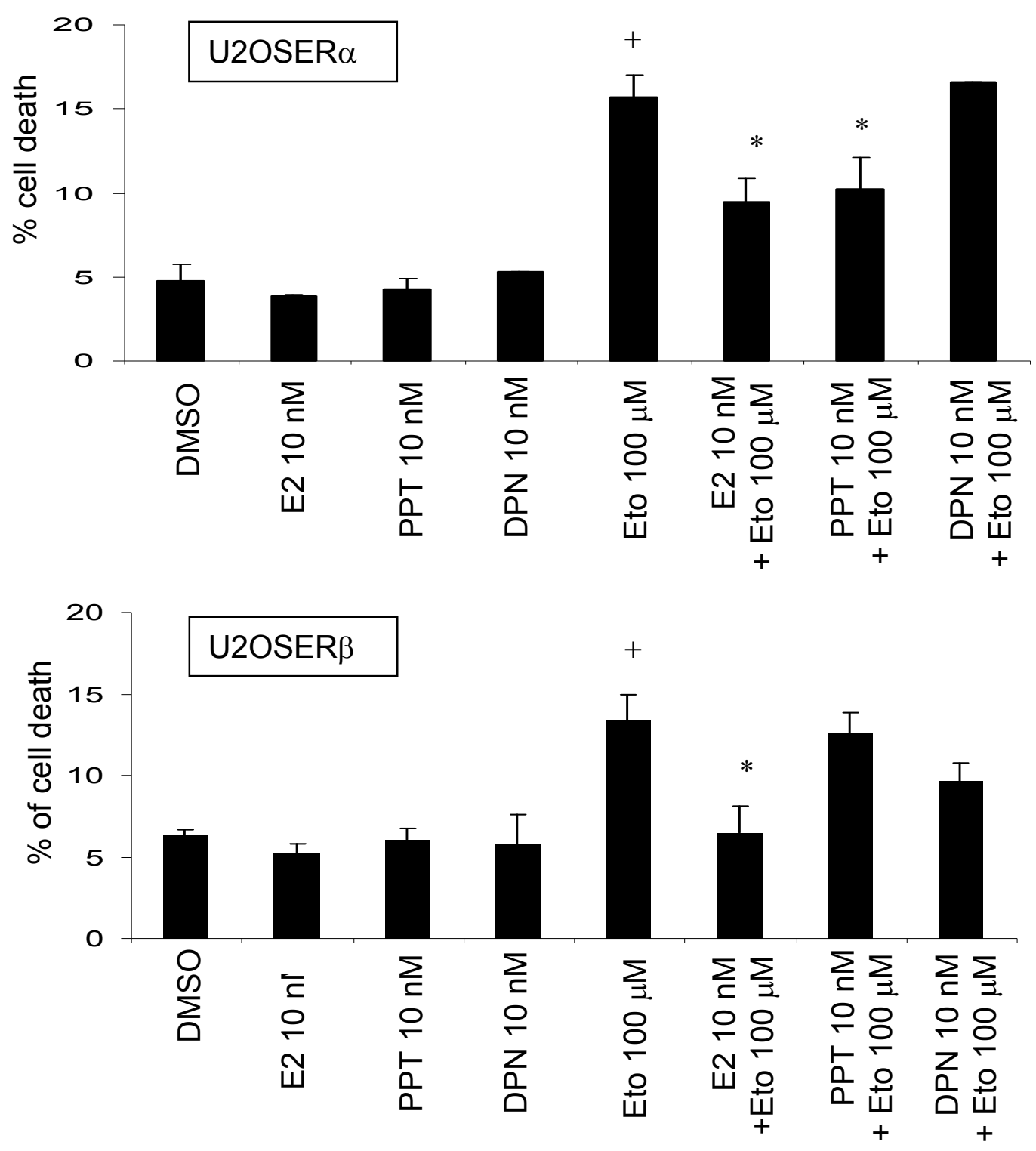

Figure 3. 
A)

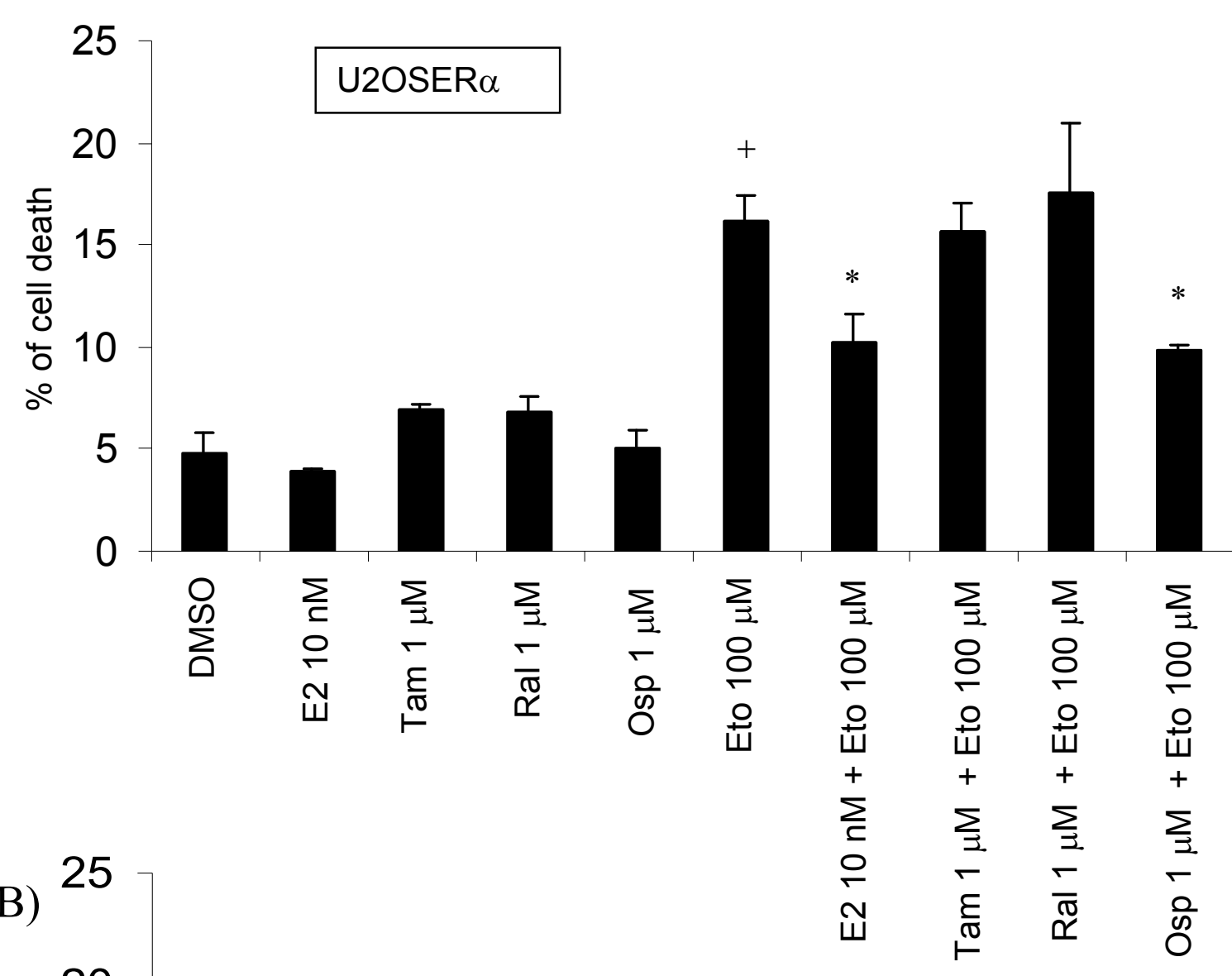

Figure 4.

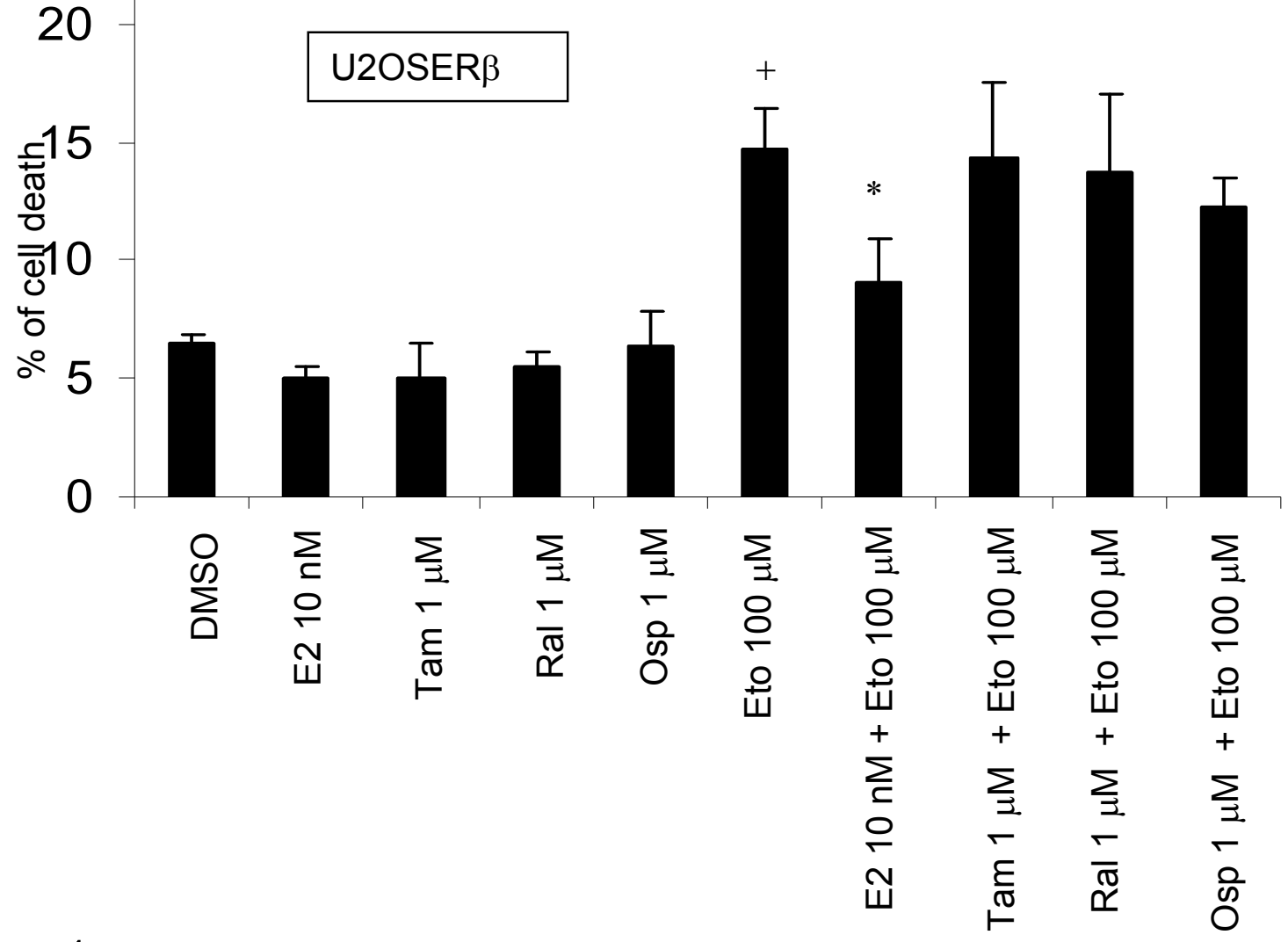




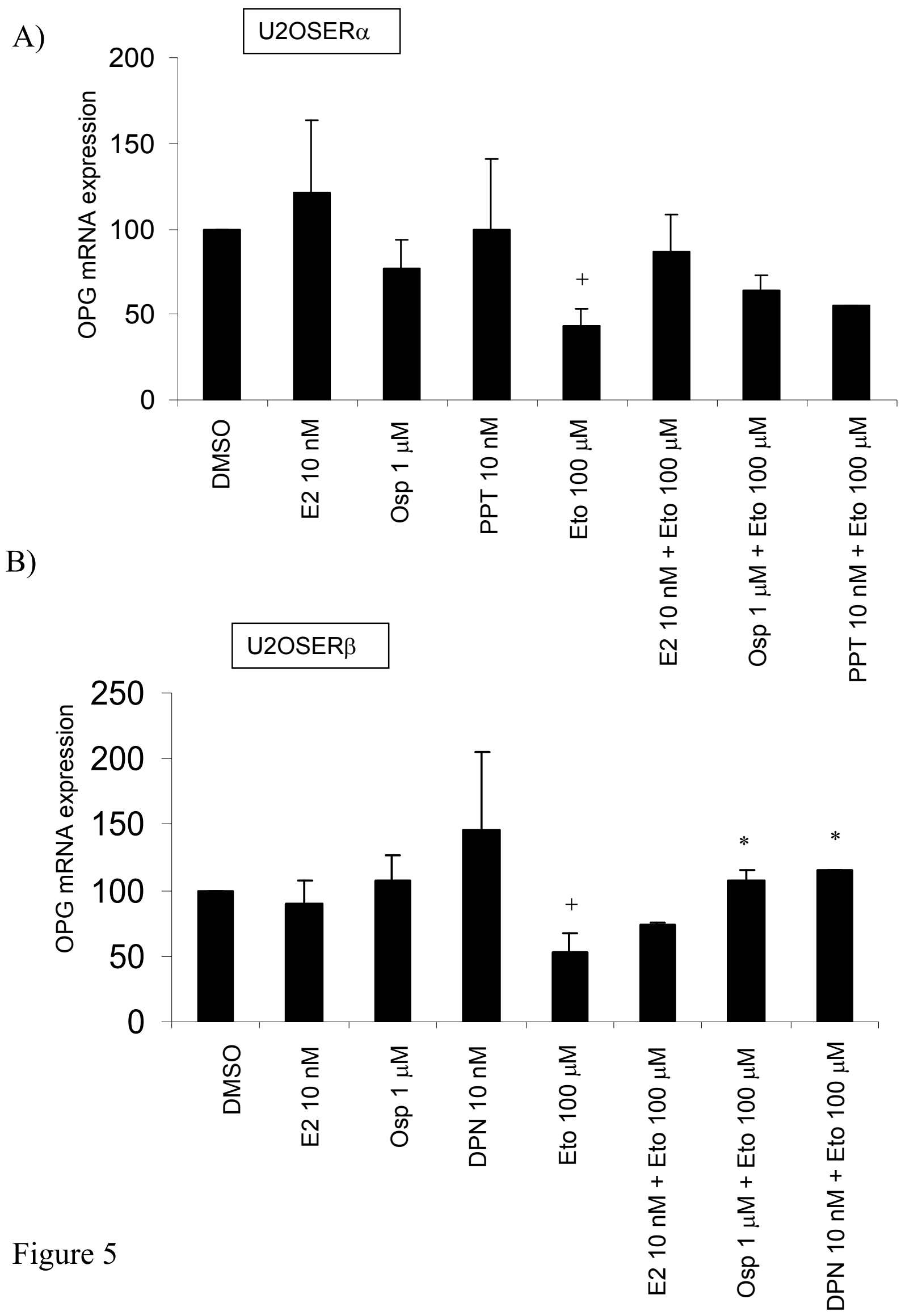

rage $4 /$ of 53 


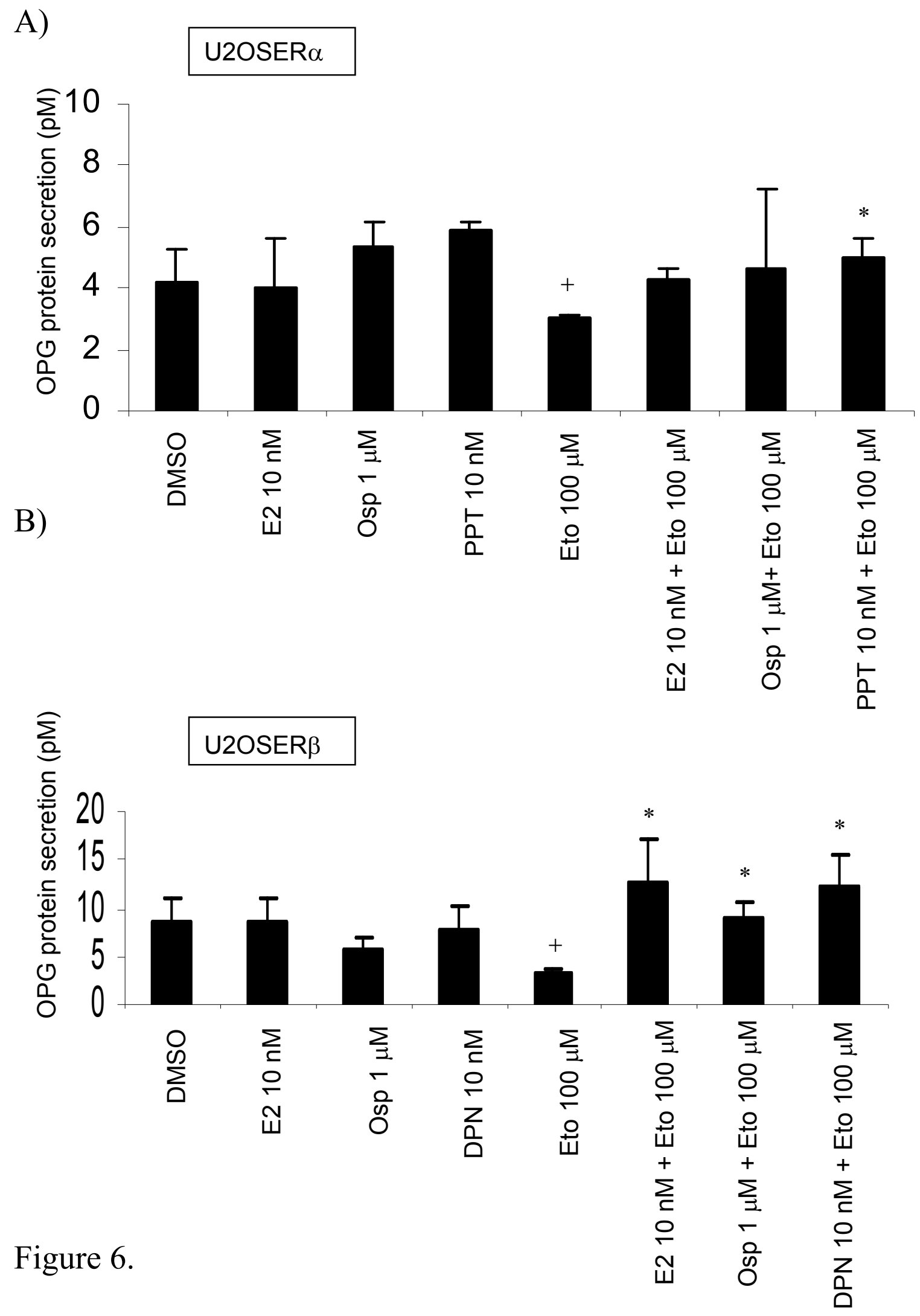


A)

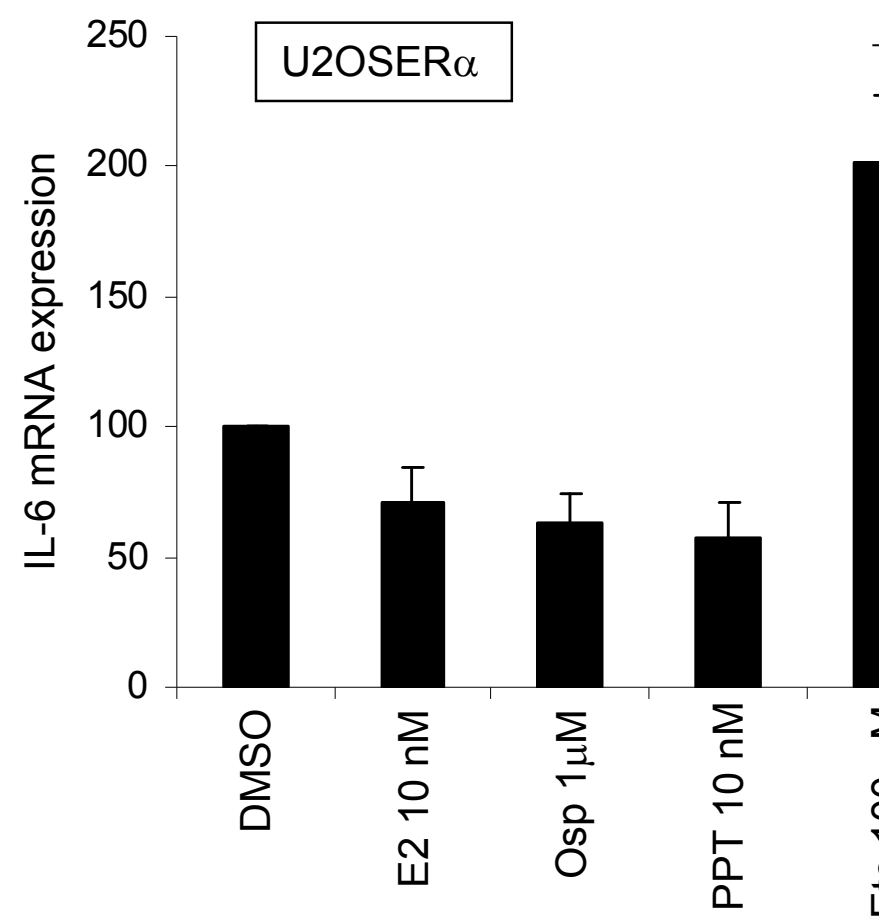

B)

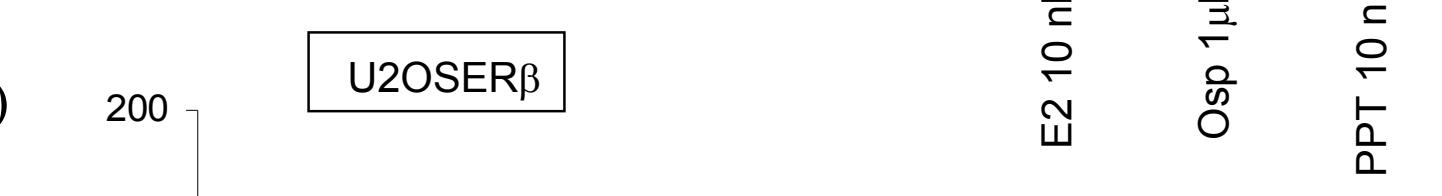

Figure 7.

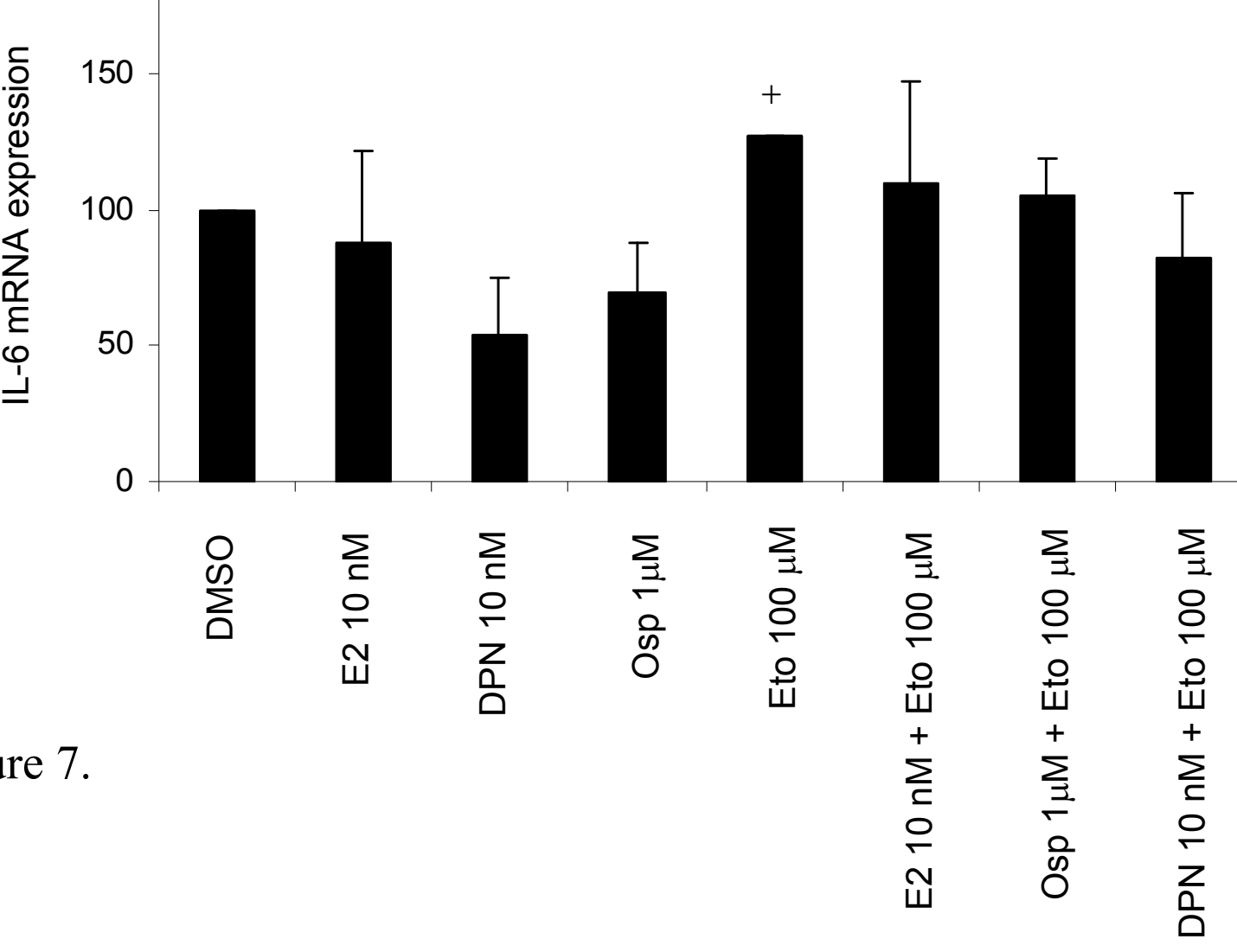


A)

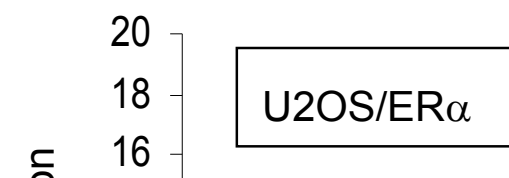

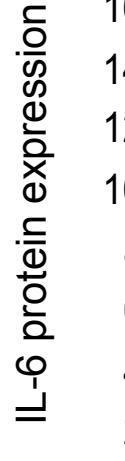

B)

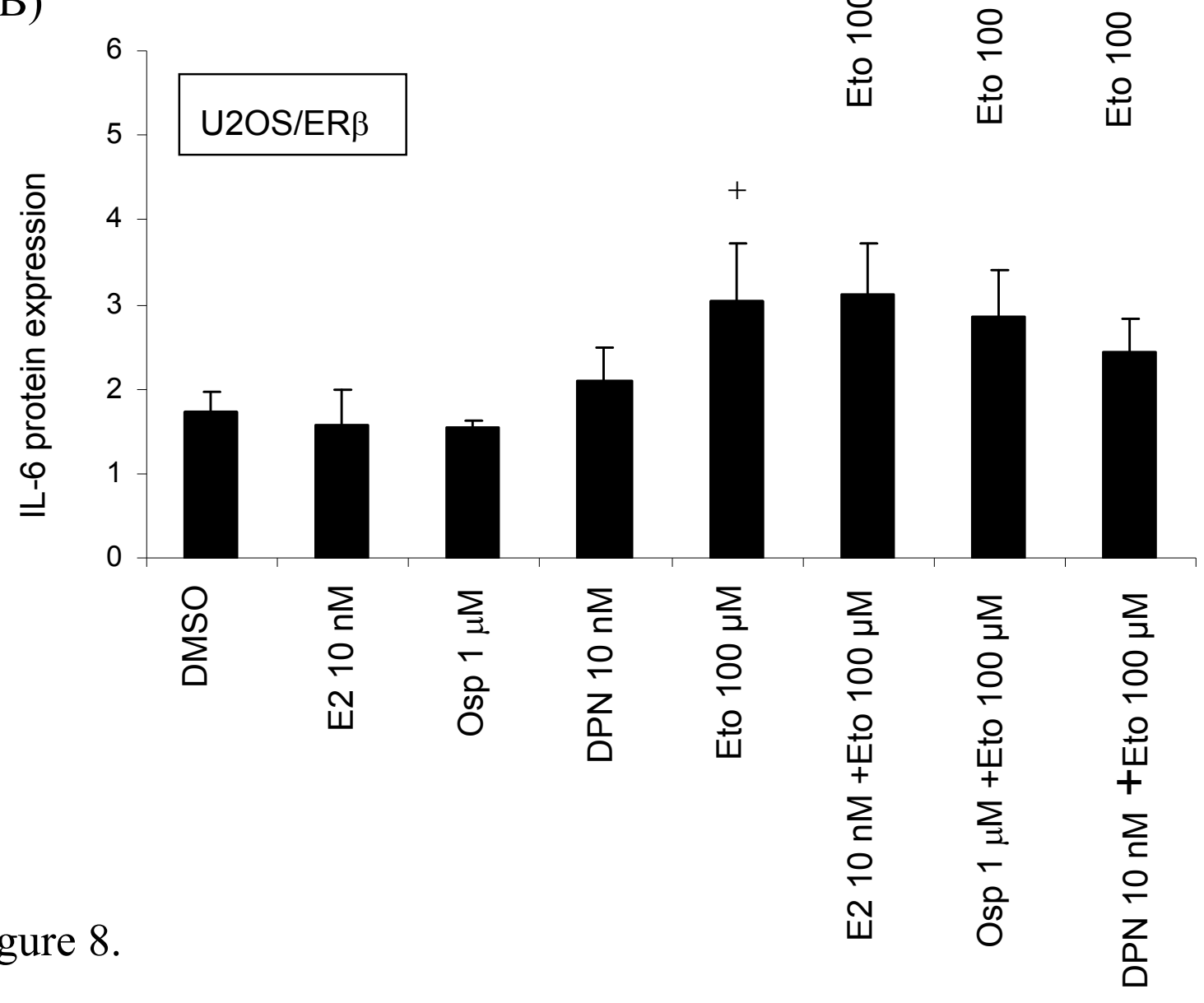




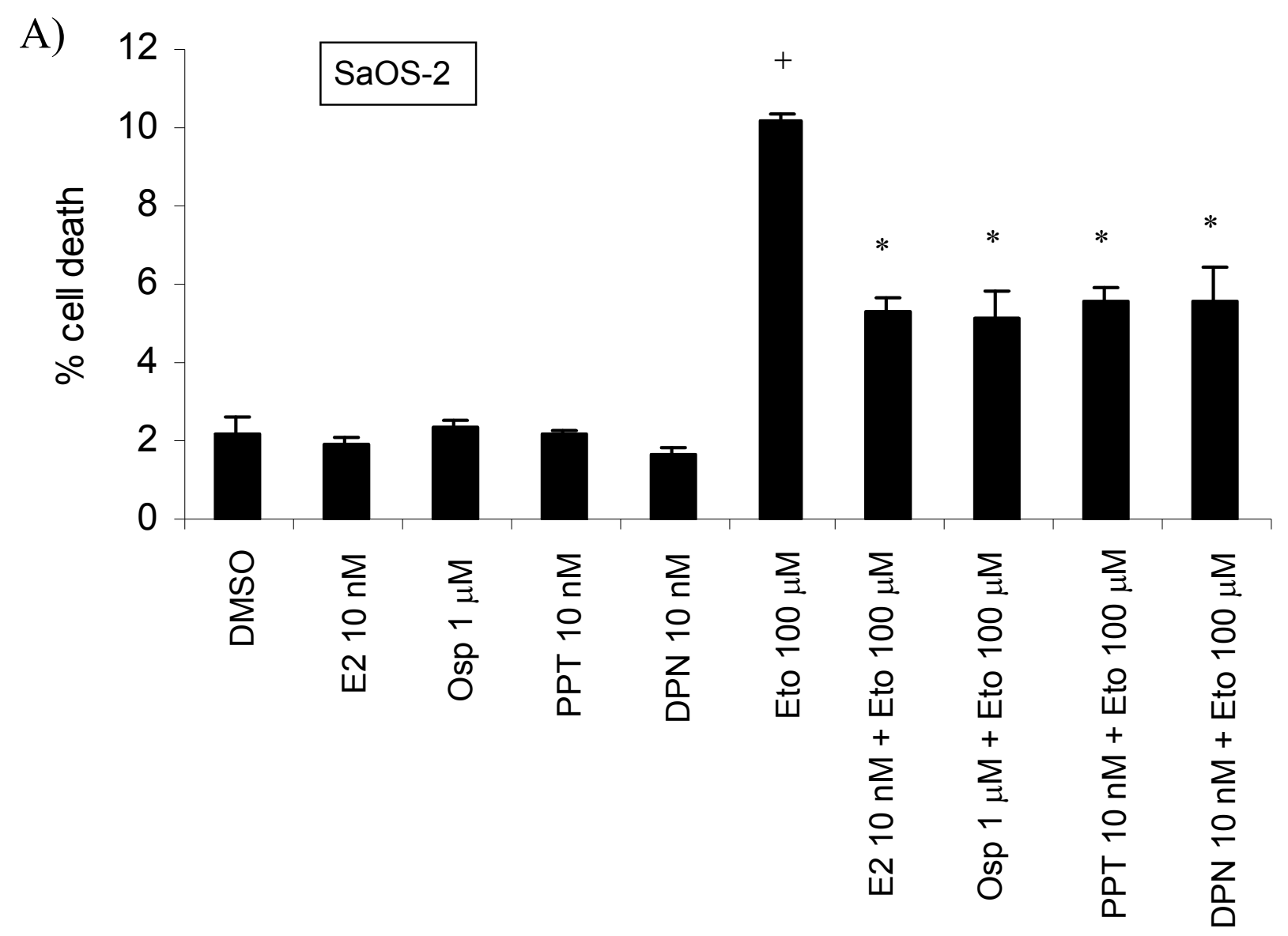

Figure 9. 
B)

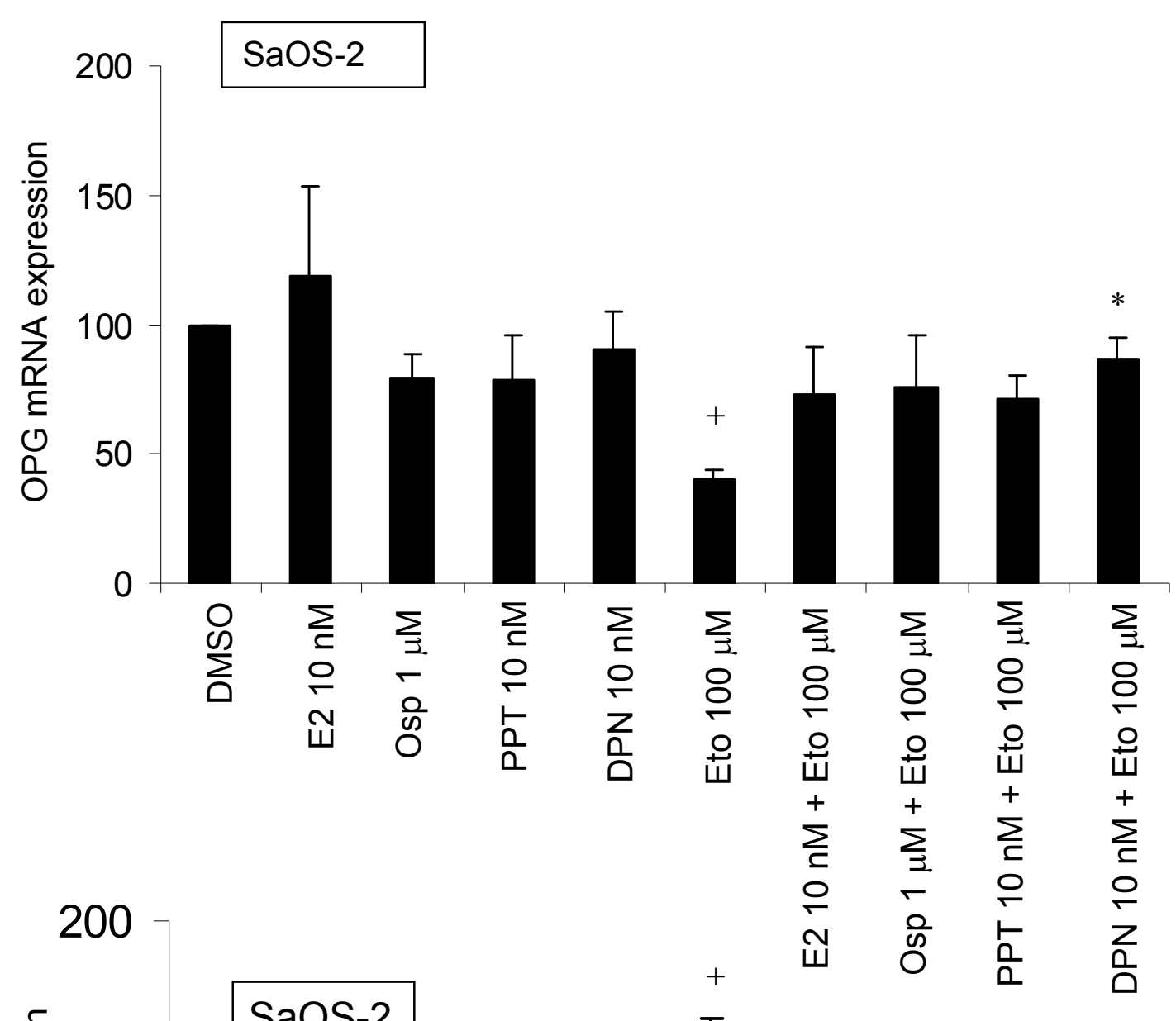

C)

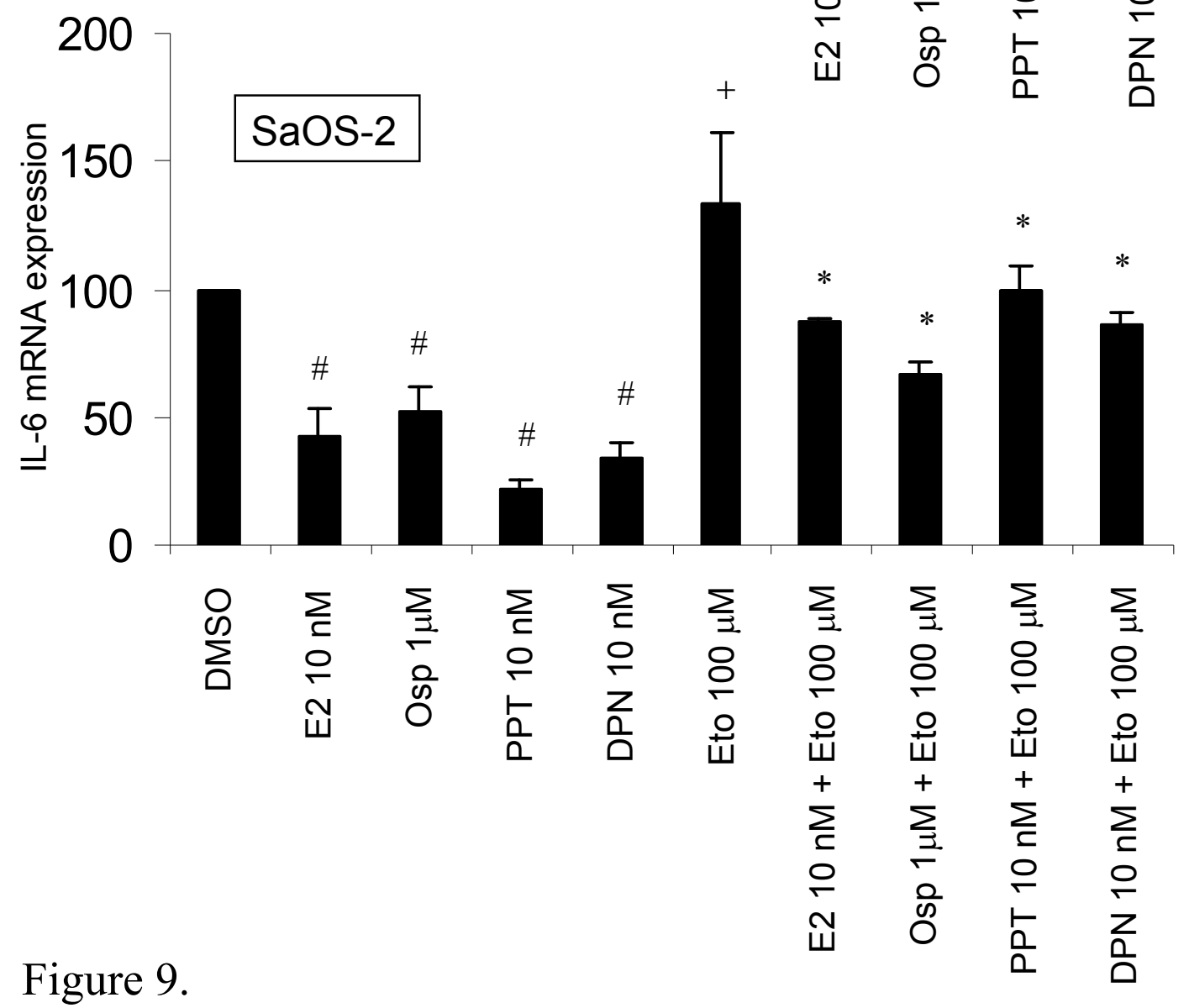


U2OS/ER $\alpha$

\begin{tabular}{|c|c|c|c|c|c|}
\hline & Cell Death & OPG mRNA & OPG protein & IL-6 mRNA & IL-6 protein \\
\hline Etoposide & $\uparrow$ & $\downarrow$ & $\downarrow$ & $\uparrow$ & $\uparrow$ \\
\hline+ E2 & $\downarrow$ & $\uparrow$ & $\uparrow$ & $\downarrow$ & $\downarrow$ \\
\hline+ PPT & $\downarrow$ & - & $\uparrow$ & $\downarrow$ & $\downarrow$ \\
\hline+ Osp & $\downarrow$ & $\uparrow$ & $\uparrow$ & - & $\downarrow$ \\
\hline
\end{tabular}

\section{$\mathrm{U} 2 \mathrm{OS} / \mathrm{ER} \beta$}

\begin{tabular}{|c|c|c|c|c|c|}
\hline & Cell Death & OPG mRNA & OPG protein & IL-6 mRNA & IL-6 protein \\
\hline Etoposide & $\uparrow$ & $\downarrow$ & $\downarrow$ & $\uparrow$ & $\uparrow$ \\
\hline+ E2 & $\downarrow$ & $\uparrow$ & $\uparrow$ & - & - \\
\hline+ DPN & $\downarrow$ & $\uparrow$ & $\uparrow$ & $\downarrow$ & - \\
\hline+ Osp & - & $\uparrow$ & $\uparrow$ & - & - \\
\hline
\end{tabular}

\section{SaOS-2}

\begin{tabular}{|c|c|c|c|c|c|}
\hline & Cell Death & OPG mRNA & OPG protein & IL-6 mRNA & IL-6 protein \\
\hline Etoposide & $\uparrow$ & $\downarrow$ & ND & $\uparrow$ & ND \\
\hline+ E2 & $\downarrow$ & $\uparrow$ & ND & $\downarrow$ & ND \\
\hline+ PPT & $\downarrow$ & $\uparrow$ & ND & $\downarrow$ & ND \\
\hline+ DPN & $\downarrow$ & $\uparrow$ & ND & $\downarrow$ & ND \\
\hline+ Osp & $\downarrow$ & $\uparrow$ & ND & $\downarrow$ & ND \\
\hline
\end{tabular}

$\uparrow=$ statistically significant increase $(\mathrm{p}<0,05)$ or a trend to increase (increase more than $20 \%$ when compared to etoposide-treated cells) $\downarrow=$ statistically significant decrease $(\mathrm{p}<0,05)$ or a trend to decrease (decrease more than $20 \%$ when compared to etoposide-treated cells) $\mathrm{ND}=$ not determined

- = no effect 